\title{
La gran rebelión de Túpac Amaru II y la temprana independencia del Perú: coincidencias, conexiones, contrastes
}

\section{The great rebellion of Túpac Amaru II and the early independence of Peru: coincidences, connections, contrasts}

Scarlett O'Phelan Godoy ${ }^{1}$

Pontificia Universidad Católica del Perú

\section{Resumen}

El artículo analiza las posibles conexiones entre la gran rebelión de Túpac Amaru y el temprano proceso de independencia en el Perú, procurando aclarar sus coincidencias y con-

1 Licenciada en Historia por la Pontificia Universidad Católica del Perú, de la cual es profesora principal en el Departamento de Humanidades, y doctora en Historia por la Universidad de Londres. Se ha especializado en el período borbónico, la independencia y la temprana República del Perú. Ha sido profesora visitante en diversas universidades extranjeras y acreedora de becas de investigación, como la John Simon Guggenheim Memorian Fundation de Nueva York, el Premio de Historia de la Fundación M. J. Bustamante de la Fuente y el Premio Georg Foster a la Investigación que concede Alemania. Se le otorgó la cátedra Simón Bolívar de la Universidad de Cambridge en el período 2008-2009. Entre sus últimas publicaciones como autora, destacan La independencia en los Andes. Una historia conectada (2014), Simón Bolivar y la conclusión de la independencia en el suelo de los incas (2019); como editora, junto con Margarita Rodríguez, El ocaso del antiguo régimen en los imperios ibéricos (2017); junto con Michael Laguerre y Mauricio Novoa, Miller. Militar, politico y peruanista (2019); y, junto con Ana Carolina Ibarra, Territorialidad y poder regional de las intendencias en la independencia de México y Perú (2019). Correo: scarlettrebeca@gmail.com; ORCID: 000-0002-7177-4471. 
trastes. Se aborda el tema a partir de la comparación de las coyunturas de ambos eventos, los programas políticos que plantearon, la composición social de ambos momentos en términos de la dirigencia y las bases, y la participación del clero; finalmente, se hace una reflexión acerca de la maduración del proceso de independencia durante el Trienio Liberal, y la llegada de San Martín y Bolívar.

Palabras clave: Túpac Amaru, Reformas borbónicas, Constitución Liberal de Cádiz, juntas de gobierno, independencia

\section{Summary}

The article analyzes the possible connections between the $\mathrm{Tu}$ pac Amaru rebellion and the early process of independence in Peru, trying to clarify their coincidences and contrasts. The issue is approached from comparing the conjunctures of both events, the political programs that they raised, the social composition of both moments in terms of the leadership and the bases, the participation of the clergy and, finally, making a reflection from the maturation of the independence process during the Liberal Triennium and the arrival of San Martín and Bolívar.

Key words: Tupac Amaru, Bourbon Reforms, Liberal Constitution of Cadiz, Juntas de Gobierno, Independence

Aunque se ha asumido y afirmado que hubo un hilo conductor entre la gran rebelión de José Gabriel Condorcanqui Noguera, Túpac Amaru II, y el proceso de la independencia del Perú, esta es una aseveración que queda aún por ser explorada y debidamente demostrada. Este ensayo se propone reflexionar sobre esta posible conexión - que no es tan nítida ni categórica-y plantear algunos argumentos al respecto, a partir de coincidencias y contrastes que se dieron entre estos dos momentos 
históricos. El estudio se centra en la temprana independencia, la de las juntas de gobierno, ya que en este período se podrá percibir con mayor claridad la continuidad y el cambio entre ambos procesos, el principal objetivo del presente análisis.

\section{Dos coyunturas distintas}

Lo primero que se debe tener en cuenta es que la gran rebelión de 1780, por un lado, y el movimiento de independencia, por otro, surgieron en dos coyunturas distintas, que se diferencian por varias razones. La rebelión de Túpac Amaru estalló dentro del contexto de las reformas fiscales borbónicas que puso en vigor el rey Carlos III durante la segunda mitad del siglo XVIII, cuando el monarca se encontraba en plenas funciones en España, rodeado de sus asesores (Fisher, 1976, pp. 109, 110, 121 y 125). ${ }^{2} \mathrm{La}$ independencia, por otro lado, se perfiló en circunstancias en que España estaba atravesando un inminente vacío de poder, al haber sido capturado y depuesto el rey Fernando VII, luego de la invasión que efectuó José Bonaparte a la cuidad de Madrid, en mayo de 1808 (Anna, 1986, pp. 58-59). ${ }^{3}$ Son, definitivamente, coyunturas bastante disímiles, distantes entre sí treinta años.

El primer contexto tiene un carácter más económico, moldeado por las reformas fiscales de Carlos III; el segundo es más político, con la formación de juntas de gobierno para regimentar España e Hispanoamérica en nombre del rey cautivo (Guerra, 1992, p. 118). En el primer caso, el detonante fue la presión económica que salpicó a todos los sectores sociales, lo que abonó el terreno para una alianza de base amplia; en el segundo, se trató de una respuesta a la invasión francesa a la península

2 Véase también el ensayo introductorio de Agustín Guimerá al libro El reformismo borbónico (1996, pp. 16-18). Guimerá pone énfasis en el entorno de Carlos III y afirma que el soberano delegaba el poder en sus ministros.

3 Véase también el libro de Josep Fontana, La crisis del Antiguo Régimen, 1808-1833 (1979, pp. 59-60). 
ibérica y el subsecuente desgobierno que supieron capitalizar, sobre todo, los criollos y mestizos, ahora denominados españoles-americanos, a quienes las cortes declararon en igualdad de derechos que los peninsulares en 1810 (Anna, 1999, p. 14). ${ }^{4}$ De esta manera, dieron curso a un reclamo recurrente que venía postergándose desde el siglo XVII (Lavallé, 1993). Quizá por esa razón, el primer artículo de la Constitución Liberal estipulaba: "La nación española es la reunión de los españoles de ambos hemisferios" (Navarro, 2000, pp. 80-82). Para los liberales españoles, esta era la alternativa factible para contrarrestar la amenaza que se cernía sobre la integridad del Imperio, donde a partir de 1809 , se venían produciendo movimientos disidentes, al considerar los españoles-americanos que la otorgada igualdad les daba derecho a constituir sus propias juntas de gobierno (Guerra, 1995, p. 25).

En la primera coyuntura, los rebeldes que secundaron a Túpac Amaru, serían acusados de lesa majestad, porque el rey se encontraba en el poder y se les imputaba estar atentando contra la fidelidad a su persona (Díaz Rementería, 1974) (véase la imagen 1).

El cacique de Tinta no negó lealtad al rey de España en ninguno de sus decretos o manifiestos; solo acusó al mal gobierno de los abusos perpetrados. Sin embargo, la proclama -posiblemente "plantada" - que se achacó haber sido hallada en uno de sus bolsillos cuando ya se encontraba en la cárcel fue considerada por muchos como una "prueba poco fiable", que, al señalarlo como José I, lo hundió en los cargos de lesa majestad. ${ }^{5}$ Este inapropiadamente denominado por algunos

4 Véase también el libro de Josep M. Fradera Gobernar colonias (1999, p. 74).

5 Para más detalles, véase el artículo de Bohumir Roedl, "Causa Túpac Amaro. El proceso a los tupamaros en Cuzco, abril-julio de 1781” (2002, p. 115). El autor afirma categóricamente -opinión que comparto- que el bando de ninguna manera fue de la autoría de Túpac Amaru y que el propio juez Benito de Mata Linares no estuvo convencido de que lo redactara el cacique de Tinta. 


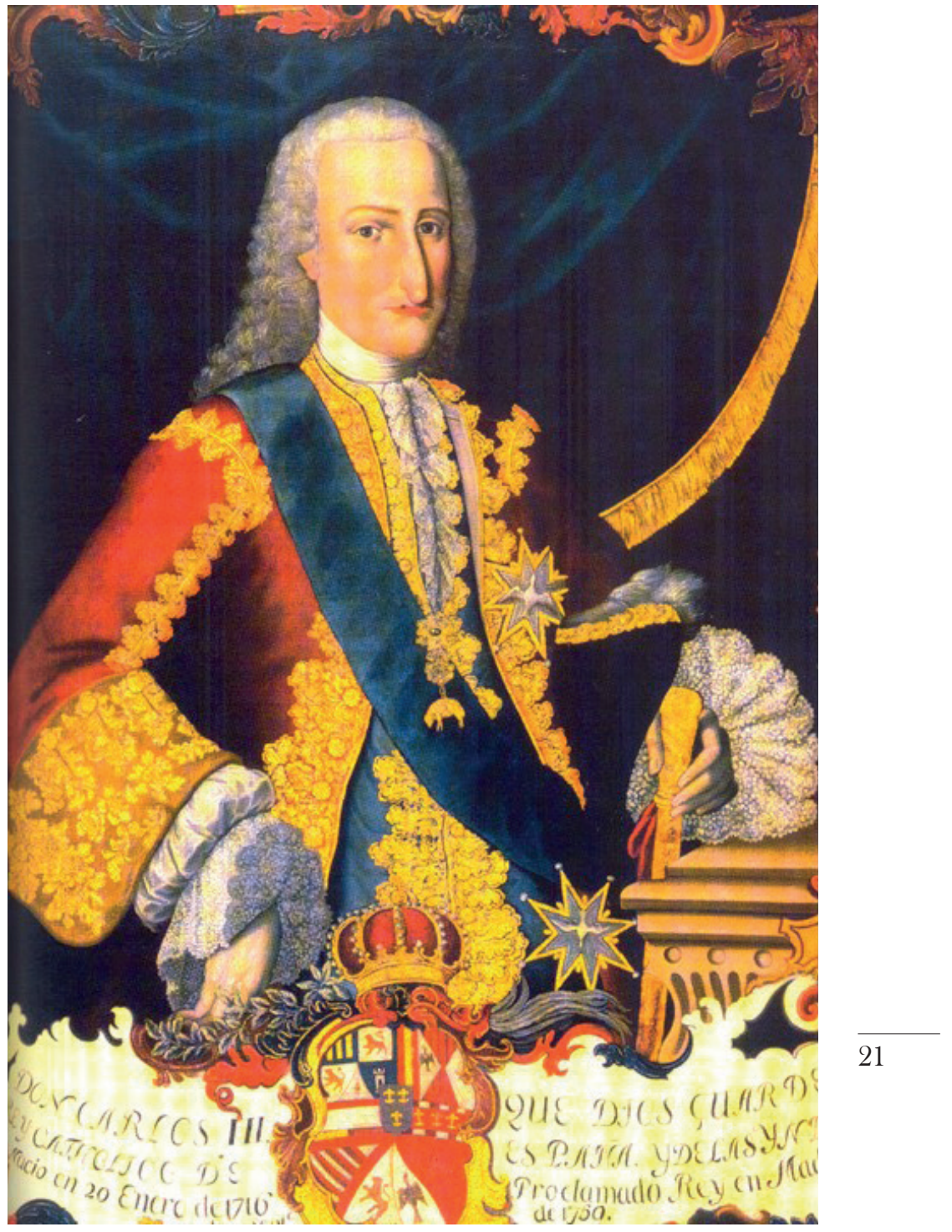

Imagen 1. Carlos III de España. Óleo sobre lienzo. Museo Virreinal Pedro de Osma, Lima. 
"bando de coronación" fue el último recurso empleado por las autoridades peninsulares para doblegarlo y ejecutarlo.

En la segunda coyuntura, las juntas de gobierno hispanoamericanas no serían reconocidas por los virreyes (O’Phelan, 2012b, p. 196), ${ }^{6}$ aunque estas apelaran a la cobertura de ejercer el poder en nombre de Fernando VII, en una clara reacción contra Bonaparte, pero con el telón de fondo de la Constitución Liberal de 1812, un reto a los cimientos de la monarquía absolutista. Fernando VII, desde su cautiverio, se mostró claramente reacio a la Constitución de Cádiz, opinión que compartía plenamente el virrey del Perú, José Fernando Abascal, para quien la Constitución Liberal era un paso hacia la democracia y, por ende, hacia la anarquía (Abascal, 1994 I, p. CIV). ${ }^{7}$ En sus propias palabras, la Constitución de Cádiz era una "monstruosa deformación" (Lynch, 1986, p. 165). A diferencia del lenguaje político de principios del siglo XIX (Peralta, 2015, p. 195) en el contexto de la gran rebelión no se menciona, ni en los manifiestos ni en los comunicados que circularon, el liberalismo, la república o la democracia, ${ }^{8}$ conceptos que adquirieron un contenido político posterior y un protagonismo en los debates de las cortes gaditanas y en las "orgías periodísticas" que desató el decreto de libertad de

6 Abascal desconoció la Junta de Huánuco y envió al intendente de Tarma, José González Prada, a reprimirla y, en el caso del Cuzco, el virrey invitó a los Angulo a deponer armas.

7 De acuerdo con Abascal, la Constitución Liberal "había introducido los principios revolucionarios de la democracia".

8 Para los conceptos de liberalismo y república, se puede consultar el libro editado por Noemí Goldman Lenguaje y revolución. Conceptos políticos clave en el Río de la Plata, 1780-1850 (2008). Particularmente de interés son los ensayos de Fabio Wasserman y Gabriel Di Meglio.

9 Tomo prestado el término orgía periodística de Jorge Basadre, pero aplicado al contexto de la Cortes de Cádiz y la efervescencia que se dio en el periodismo de esos ańos tanto en España como en Hispanoamérica. Para 
prensa del 10 de noviembre de 1810, que tanto disgustó al virrey del Perú (Puente Candamo, 1992, p. 106). ${ }^{10}$

En todo caso, cuando se habla del detonante de un movimiento social, se hace referencia al evento que encendió la mecha, que precipitó el estallido, sin que eso signifique, necesariamente, obviar que hubo otras variables irresueltas que también emergieron en el contexto de intranquilidad social y presionaron por un espacio en las agendas políticas. En este sentido, si bien en el movimiento de Túpac Amaru las protestas visibles tienen carácter fiscal, eso no quiere decir que no se hubiera incubado malestar de parte de criollos y mestizos por ser consistentemente postergados de los puestos de gobierno (Lynch, 1996, p. 45), ${ }^{11}$ o que no existiera inquietud en las comunidades y la élite indígena por la manera como los corregidores estaban adulterando el cargo de cacique, colocándolos a dedo, para que les garantizaran el cobro de sus repartos sin respetar la tradicional sucesión cacical (O’Phelan, 1997, p. 20). ${ }^{12}$ Así mismo, las tempranas juntas de gobierno, su creación en nombre de Fernando VII y la decisión de proceder al cambio de autoridades no impidieron que paralelamente se barajara decretar la abolición de los monopolios, aduanas, alcabalas y, eventualmente, tributos (O’Phelan, 1988, pp. 79-80).

el caso del Perú, no pierde vigencia el libro de Ascensión Martínez Riaza, La prensa doctrinal en la independencia del Perú, 1811-1824 (1985).

10 De la Puente denomina a Abascal, el último virrey clásico (1992, p. 118).

11 De acuerdo con Lynch, Carlos III desmontó el Estado criollo y restauró la hegemonía española. Por su parte, Mark Burkholder (1972) atribuye al ministro José de Gálvez (1776-1787) la política de reducir la influencia del sector criollo en el Gobierno colonial.

12 Los caciques eran nominados a "devoción y antojo" del corregidor. 


\section{Las agendas políticas y sus alcances}

Las reivindicaciones que se enfatizan en los motines precedentes a la gran rebelión están relacionadas con las medidas traídas en cartera por el visitador José Antonio de Areche al Perú en $1777 .{ }^{13}$ Sin embargo, hay que admitir que ya habían surgido algunos altercados previos en torno al establecimiento de las primeras aduanas en Cochabamba y La Paz a causa de la presencia de funcionarios traídos de fuera para dirigirlas y de la rigurosa política que se estaba aplicando en la medición y peso de los productos introducidos (O'Phelan, 2005, pp. 20-21 y 25-26). ${ }^{14}$ No obstante, con Areche la presión fiscal se agudizó al ponerse en vigor un esquema impositivo más severo que incluía el alza de la alcabala del $4 \%$ al $6 \%$, la creación del nuevo impuesto de $12.5 \%$ sobre el aguardiente, la inclusión de productos de la tierra tradicionalmente exentos del pago de alcabalas, la propuesta de ampliar el tributo a mestizos, zambos y mulatos, y los catastros sobre propiedades agrarias y obrajes (O'Phelan, 2012a, pp. 229-230). ${ }^{15}$ Es decir, las medidas tenían un claro contenido económico, pero, sobre todo, daban pie a la creación de una platafor-

13 Ese mismo año se produjo, en el Cuzco, la rebelión de Maras, Urubamba; en esta, se señaló a un Tupa Amaro como el autor de un memorial a partir de la denuncia hecha por Estaban Zúñiga, que por falta de pruebas quedó descartada (O’Phelan, 2012a, pp. 213, 214).

14 Las referencias son alusivas a los ataques a las aduanas de Cochabamba, en 1774, y La Paz, en 1777, ambas ubicadas en el Alto Perú. Hay información complementaria en mi libro Un siglo de rebeliones anticoloniales. Perú y Bolivia, 1700-1783 (2012a, pp. 201-226). Siempre es de interés consultar el libro de Boleslao Lewin, La rebelión de Túpac Amaru y los orígenes de la independencia de Hispanoamérica (1967, pp. 148-180).

15 El tema también lo desarrollo en el artículo, "Entre Gálvez y Areche: el factor acumulativo de presión fiscal y la gran rebelión de 1780" en el libro Historias paralelas. Actas del Primer Encuentro de Historia Perú-México (Guerra y Rouillon, 2005, pp. 225-227). 
ma de base ancha, en la que se encontraran representados los intereses de todos los sectores sociales de la población. Además, hay que admitir que, en esta plataforma política, se incluyeron también resquemores de carácter social, como la contrariedad que significaba para los mestizos, zambos y mulatos el hecho de que se les rebajara socialmente a la categoría de tributarios con el fin de incrementar los ingresos de las arcas reales. Esta medida empujó a los mulatos y zambos a incorporarse a las protestas, en las que hicieron explícito su rechazo e indignación (Cahill, 1990, p. 271). ${ }^{16}$

Durante la gran rebelión, las protestas tuvieron un carácter general y vinieron de parte de los pequeños agricultores y comerciantes indígenas, de arrieros mestizos, artesanos indígenas y mestizos, de criollos productores y comerciantes, $\mathrm{y}$ hasta de hacendados y obrajeros peninsulares. El tributo y la mita no jugaron un papel central en el pliego de reclamos de la "sublevación general". Túpac Amaru suspendió el tributo al ser presionado por las comunidades de Lampa, pero precisó que era una exoneración temporal, mientras estuviera vigente la rebelión (O’Phelan, 1995, p. 199). ${ }^{17}$ Esta fue una concesión frente a lo que había especificado antes en Huaro: "que [los indios] solo le habían de pagar a él los tributos". ${ }^{18}$ Respecto de la mita, se centró en la minera, sin aludir a la mita chacra o a la mita obraje que también pesaban sobre los indios de comunidad. A pesar de ello, hasta avanzada la re-

16 Se advirtió que, si a los cholos y zambos se les cobraba tributo, estos se levantarían. Además, se registró la presencia de mulatos a caballo que trataron de indagar sobre los alcances del tributo. Véase también el libro de Guillermo Galdós Rodríguez, La rebelión de los pasquines (1967), en el que se transcriben algunas fuentes primarias.

17 Según el reo Marcos Poma, Túpac Amaru había ofrecido liberarlos de los tributos por tres años, luego de los cuales tenían que continuar contribuyendo como siempre (AGI Audiencia del Cuzco, leg. 32).

18 AGI Audiencia del Cuzco, leg. 32. Confesión de Esteban Escarcena. 
belión, se siguieron enviando mitayos del surandino peruano a Potosí (O’Phelan, 1995, p. 197) ${ }^{19}$ sin haberse prescrito su suspensión, obviándose que, desde 1776 , las minas potosinas pertenecían al recientemente creado virreinato del Río de la Plata. Es decir, en 1780, aún se estaban trasladando mitayos de un virreinato a otro sin haberse realizado los correspondientes ajustes jurisdiccionales, a pesar de que el cacique abordó el tema de la mita minera en alguno de sus comunicados. Así, pese a los repetidos reclamos de las comunidades, ni tributo ni mita resultaron prioritarios en el programa de Túpac Amaru II. Más bien, se hizo énfasis en el paquete económico traído por Areche y también en el reparto de mercancías que, hasta 1780, seguía en vigor a pesar de atribuirse al visitador, que arribó en 1777, ser portador de una real cédula para anularlo. Esto se diferencia de lo que ocurrió en el caso de las Cortes de Cádiz entre 1810 y 1814, y, sobre todo, del espíritu de la Constitución Liberal de 1812, que promovió a los indios al estatus de ciudadanos -apelando a la igualdad de derechos- (Chust, 1999, p. 159); para ello, se decretó la abolición del tributo en 1811, y la derogación de la mita o servicios personales en 1812 (O'Phelan, 2007, p. 284). ${ }^{20}$ En consecuencia, las Cortes de Cádiz dan la impresión de haber propugnado cambios más estructurales y radicales que los adoptados durante la gran rebelión.

Así, con la invasión napoleónica y la formación de juntas de gobierno en Espańa y América, el trasfondo inicial tuvo un carácter más político que económico, por lo menos bajo este argumento fue expuesto el apoyo a Fernando VII (Puente

19 Como expresó Julián Apaza, alias Túpac Catari, "a los últimos de la sedición estaban asimismo a quitar la mita de Potosí”, es decir, en 1781, durante la segunda fase o fase aimara (AGI Audiencia de Charcas, leg. 319).

20 El tema también se trabaja en el artículo de Christine Hünefeldt, "Los indios y la Constitución de 1812" (1978). 


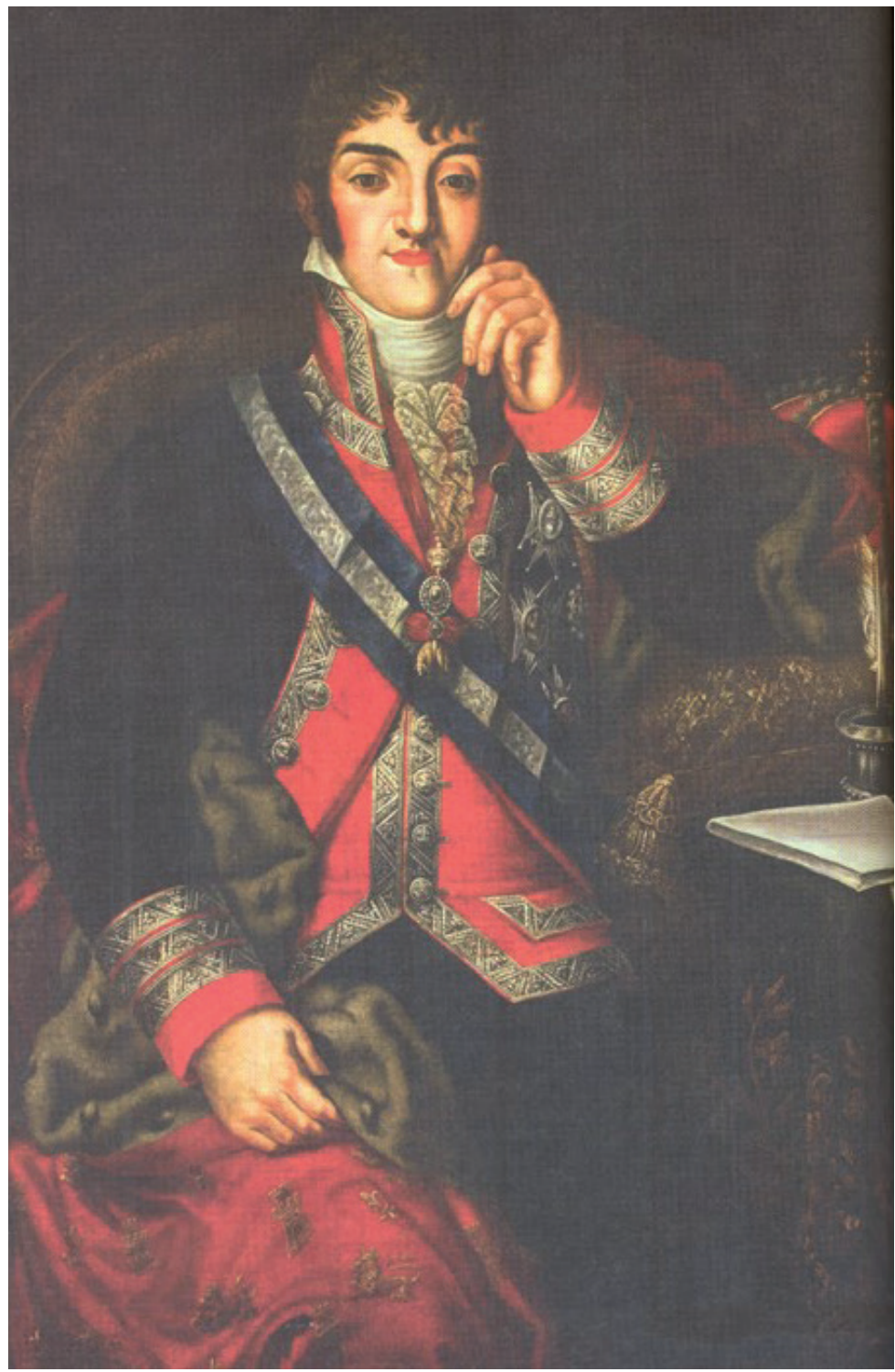

Imagen 2. Fernando VII, El Deseado. Óleo sobre lienzo de Gil de Castro. Museo Nacional de Arqueología, Antropología e Historia del Perú, Lima. 
Candamo, 1992, p. 93) ${ }^{21}$ (véase la imagen 2). Sin embargo, eso no implica que posteriormente, en los debates en las Cortes de Cádiz, se aborden con frecuencia temas de índole económica, como el libre cultivo, la abolición de los monopolios, la rebaja de los censos de $5 \%$ al $3 \%$, la libertad de manufactura e industria, y los recursos agrícolas explotables en las colonias (Rieu-Millan, 1999, pp. 183-185, 187). No obstante, el detonante de estas protestas fue defender el trono del rey cautivo, aunque ello no sería mella para buscar en Hispanoamérica autonomías regionales, cambio de autoridades, y reivindicaciones que estaban en proceso de otorgarse y que se intentó acelerar.

La Junta Tuitiva de La Paz de 1809 advertía que no quería depender ni de Lima ni de Buenos Aires, y demandaba una autonomía regional (Roca, 2007), ${ }^{22}$ mientras que, también en 1809, la Junta Soberana de Quito trató de implementar el proyecto que había dejado en 1805 sobre el tapete el presidente saliente, barón de Carondelet, cuyo objetivo era hacer de la audiencia quiteńa una capitanía general (Larrea, 1969, pp. 160, 168). ${ }^{23}$ En 1814, la Junta del Cuzco, por su parte, envió columnas militares a Huamanga, Arequipa y La Paz; de esta manera, delineó el espacio que pretendía abarcar (O’Phelan, 1984, p. 60). Esta delimitación recuerda el proyecto del clérigo zaragozano Francisco Carrascón y Solá, racionero de la catedral del Cuzco, que planteaba erigir una capitanía general entre el Bajo y el Alto Perú, cuya capital

21 El 13 de octubre de 1808, el cabildo realizó la proclamación de Fernando VII no solo en Lima, sino en las diversas intendencias y en lugares tan remotos como Maynas.

22 Véase también el libro de Charles W. Arnade, The Emergence of the Republic of Bolivia (1957), y el trabajo de René Arze Aguirre, Participación popular en la independencia boliviana (1979).

23 Para el contexto de la junta quiteña, se puede consultar el libro de José Gabriel Navarro, La revolución de Quito del 10 de agosto de 1809 (1962). 
iba a ser Cuzco o Puno; dicho sacerdote había sometido esta propuesta al rey en $1801 \mathrm{y}$, en principio, fue rechazada tanto en Lima como en Madrid (Fisher, 1979, p. 239). Incluso el propio Túpac Amaru dejó entrever la posibilidad de que el surandino funcionara como una capitanía general con sede en el Cuzco (Madrazo, 2002, p. 21), ${ }^{24}$ para lo cual era inminente la creación de una audiencia, postulado retomado y posteriormente elaborado más a fondo por el cura Carrascón.

Es interesante que, a partir de 1805, Quito reclamara conformar una capitanía general, ya que, solo algunos años antes, el Bajo y el Alto Perú habían hecho lo propio, con el plan sometido por Carrascón en 1801 a la Corona. Con ello, ambos espacios esperaban alcanzar conjuntamente una autonomía regional, pero manteniendo una estructura geopolítica instaurada en la colonia. Es más, de crearse la capitanía general que proponía Carrascón, el surandino habría contado con dos audiencias: una en el Bajo Perú, ubicada en el Cuzco, y la otra en el Alto Perú, situada en Chuquisaca. Las capitanías generales, que a la sazón funcionaban en Chile y en Caracas, contaban cada una con una sola audiencia. En ese sentido, habría resultado un tanto inusitado y costoso contar con dos audiencias en el caso del surandino, salvo que el proyecto fuera crear una capitanía general en el Bajo Perú y otra en el Alto Perú, lo cual no queda suficientemente claro. Vale recordar que el propio virreinato del Perú, recién consiguió tener su segunda audiencia, la del Cuzco, en 1787, la cual entró en funciones un año después (Torero Gomero, 1969-1971, pp.

24 En el juicio seguido a la gran rebelión, Micaela Bastidas declaró que Túpac Amaru mandó que le pintaran un retrato, pues pensaba enviarlo a España para que el rey lo conociera. En palabras de Andrés Mendigure, Túpac Amaru era comisionado de su majestad y después quedaría como virrey en Lima. Para más detalles, véase Scarlett O’Phelan Godoy, Siete ensayos sobre la gran rebelión de los Andes: de Túpac Amaru a Túpac Catari (2016, pp. 203-213). 
412-415). ${ }^{25}$ Para 1814, Carrascón, lo mismo que el anciano obispo del Cuzco, José Pérez Armendáriz, expresó su simpatía por el movimiento insurgente de los Ángulo y por el contenido de los acuerdos de la Constitución Liberal (Molina Martínez, 2010, p. 210). ${ }^{26}$ De un arzobispo y cinco obispos que en ese momento se encontraban en funciones, solo el obispo cuzqueño Pérez Armendáriz se identificó con la causa revolucionaria (Klaiber, 2001, p. 128). Con esta postura, legitimó la cobertura religiosa del movimiento cuzqueño, aunque en 1814 no se llegó a articular una alternativa política coherente (Iberico, 2016, p. 281) que lograra unificar el Bajo y el Alto Perú, un planteamiento integracionista que también se había dejado entrever en la Junta de La Paz de 1809 al enviarse, desde un inicio, comunicados de convocatoria a las provincias de Cuzco, Arequipa, Puno y Cochabamba (O’Phelan, 1984, p. 64). ${ }^{27}$

\section{La composición social: dirigencia y bases}

Como ya se ha establecido, en la gran rebelión y, sobre todo en su estadio más temprano, la composición social del movimiento fue mixta, con una aparente diversidad étnica, aunque siempre con un mayor peso del componente indígena, que en gran medida conformó la tropa. Si bien la cabeza visible de la insurrección fue, sin duda, el cacique interino José Gabriel Túpac Amaru, un mestizo real, ${ }^{28}$ este se rodeó tempranamente de dos peninsulares casados con criollas, además de varios criollos

25 Para el cargo de regente de la audiencia fue nombrado José de la Portilla, quien llegó al Cuzco el 23 de junio de 1788 e inauguró el tribunal el 3 de noviembre del mismo año.

$26 \mathrm{Al}$ momento de la insurrección, el obispo Pérez Armendáriz, natural de Urubamba, tenía 85 años.

27 Declaraciones de Pedro Domingo Murillo.

28 Por el lado materno, Túpac Amaru tenía sangre mestiza (Del Busto, 1981, p. 32). El nombre de su madre era Rosa Noguera Valenzuela, mestiza nacida en Tinta. 


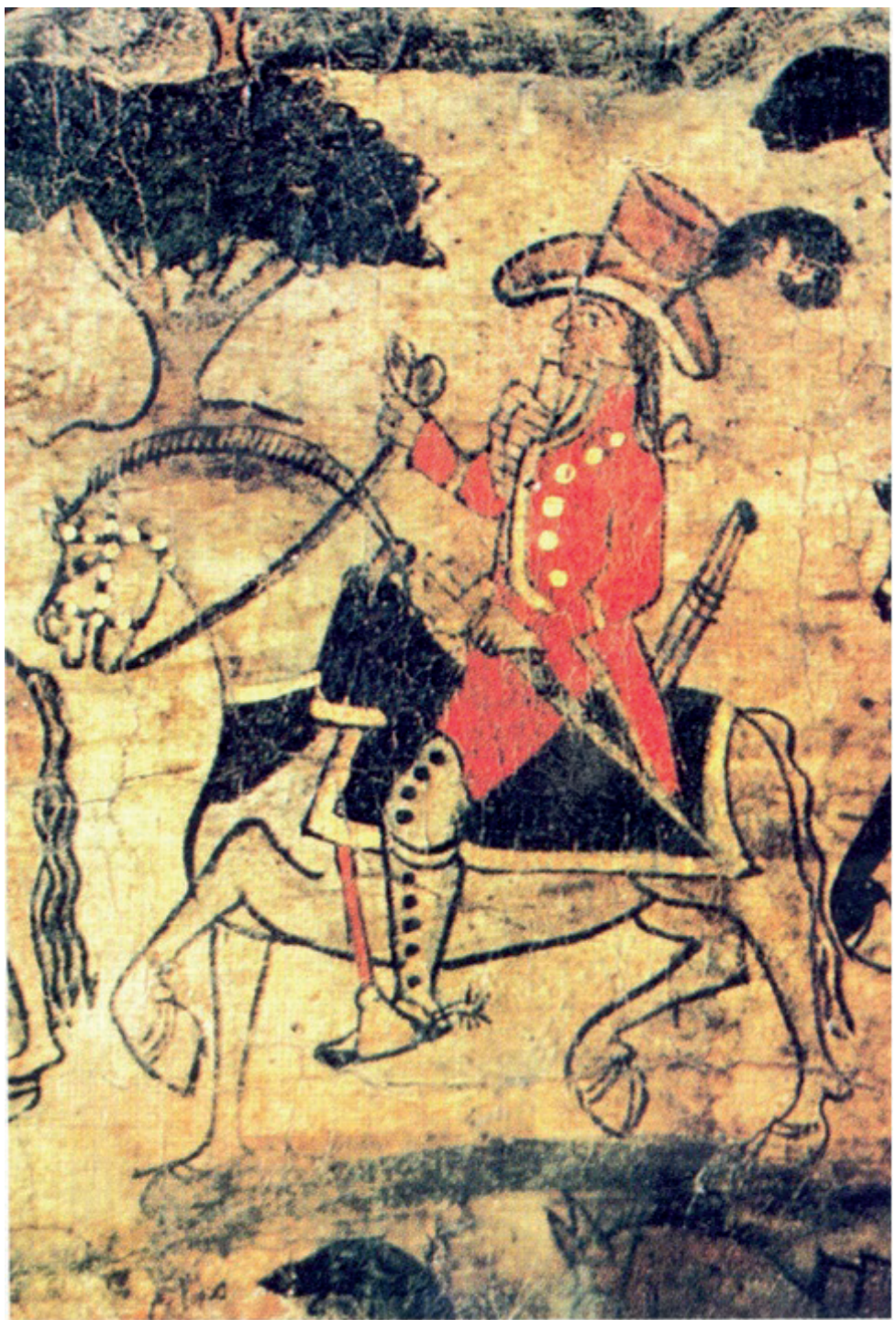

Imagen 3. José Gabriel Túpac Amaru II retrato ecuestre. Cacique interino de Tungasuca. Temple sobre cuero de cabra atribuido a Tadeo Escalante. Cortesía de Pablo Macera. 
que actuaron como escribanos, armeros, cajeros, administradores, todos ubicados en la cúpula de la dirigencia, pero que eran resguardados de ir al frente (véase la imagen 3). En el liderazgo de su ejército, el cacique rebelde contó con varios mestizos que promovió al rango de capitanes y coroneles; a estos se sumó más de una veintena de caciques que lo secundaron y aportaron hombres, armas y bastimentos, de cuyo acopio y distribución se encargó Micaela Bastidas (O'Phelan, 2012a, p. 254-255, 271-272). ${ }^{29}$ Adicionalmente, Túpac Amaru tuvo el buen criterio de colocar, desde un principio, a sus parientes cercanos - como Diego Cristóbal Túpac Amaru, Miguel Bastidas y Andrés Mendigure- en ubicaciones estratégicas dentro de los cuadros militares del movimiento. Esta inteligente decisión permitió que, al ser apresado el cacique de Tinta, en abril de 1781, sus parientes, que además eran sus hombres de confianza, asumieran el liderazgo de la gran rebelión; de este modo, se logró una transición sin mayores tropiezos entre la primera y la segunda fase del movimiento.

Sin embargo, en términos de la composición social de la "sublevación general", hubo un punto de inflexión que revirtió su multietnicidad inicial, al producirse el 18 de noviembre, a poco más de una semana de haber comenzado el movimiento, la batalla de Sangarará, que significó un celebrado triunfo para las huestes rebeldes y la subsecuente excomunión de José Gabriel Túpac Amaru, sanción que lo ponía a la par del malogrado corregidor Arriaga, quien había sido excomulgado en el mes de julio (Walker, 2014, p. 37). ${ }^{30}$ En este sentido, el cacique de Tinta debió aceptar que las masas indígenas se habían desbordado del control de la dirigencia ante el fragor

29 AGI Audiencia del Cuzco, legs. 32 y 33. Los criollos cercanos a Túpac Amaru fueron Diego Ortigoza, Francisco Molina, Mariano Banda y Manuel Galleguillos.

30 El tema del desencuentro del corregidor Arriaga con el obispo Moscoso y la curia cuzqueńa es desarrollado por el autor. 


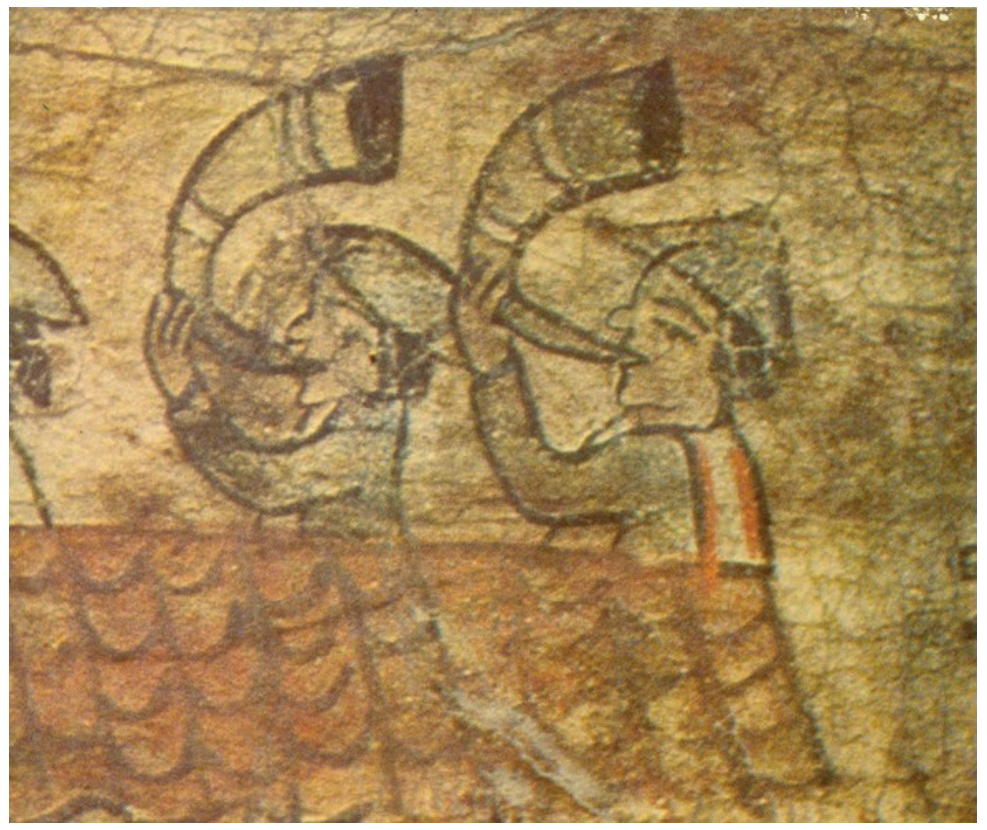

Imagen 4. Escena de la batalla de Sangarará. Temple sobre cuero de cabra atribuido a Tadeo Escalante. Cortesía de Pablo Macera

de la batalla y que, al quemarse la iglesia, los peninsulares y criollos que se habían posesionado de ella salieron despavoridos huyendo del incendio y encontraron la muerte a manos de los rebeldes, quienes los aguardaban afuera (Lewin, 1967, pp. 449-450) ${ }^{31}$ (véase la imagen 4).

Además, se debe tener presente que precisamente el día anterior -17 de noviembre- había sido ahorcado el cacique de Pisac, Bernardo Tambohuacso, a quien se le imputaba com-

31 También se puede consultar el libro de Alberto Flores Galindo, Buscando un inca: identidades y utopía en los Andes (1987, p. 134). Se señala que, si bien Túpac Amaru pretendía respetar a los curas y a la Iglesia, en Pampamarca, los rebeldes saquearon la ropa y los ornamentos de los templos. 
plicidad en la conspiración de plateros del Cuzco (Durand Flórez, 1985, p. 188). Los ánimos de los pobladores indígenas debían haber estado caldeados, de ahí que es posible observar que de Sangarará en adelante, se produjo un repliegue del grupo de criollos que acompañó a Túpac Amaru en los albores del movimiento y empezó la deserción de varios de ellos. ${ }^{32}$ Luego de este temprano incidente, la rebelión se convirtió, fundamentalmente, en una insurrección conformada por mestizos e indígenas con una modesta presencia de las castas de color (O'Phelan, 2012a, pp. 340, 347, 354). ${ }^{33}$

Aunque se ha planteado que un rasgo indicativo de la continuidad entre la gran rebelión y la primera fase de la independencia es la presencia de los mismos personajes en ambas coyunturas, habría que explorar más a fondo esta conexión y observar cuál fue el comportamiento de estos individuos en 1780-1781 y, luego, en el caso concreto del Cuzco, su actuación en 1814. Que estén en la arena política en ambos momentos no significa, necesariamente, que su trayectoria haya sido consecuente.

Por ejemplo, un personaje que estuvo en ambas coyunturas fue el cacique de Chinchero, Mateo Pumacahua, pero jugó un papel muy distinto en el siglo XVIII del que desempeñó en el temprano XIX. Pumacahua se declaró abierto opositor a la gran rebelión y al cacique de Tinta en 1780-1781, mientras que, a la vuelta del siglo, conformó, en 1814, la junta de

32 AGI Audiencia de Lima, leg. 1039. Varios criollos y mestizos desertaron luego de la "matanza" de Sangarará, aunque el obispo Moscoso atribuyó las deserciones a la excomunión que aplicó contra Túpac Amaru, su familia y sus huestes.

33 Los implicados llevados a juicio en la gran rebelión, que pertenecían a las castas de color fueron Gerónimo Andía, zambo de oficio sastre; Antonio Oblitas, mulato libre de oficio pintor; y Manuel Bustíos, descrito como moreno y que ejercía de clarinero. 
gobierno encabezada por los hermanos Angulo en el Cuzco. Es decir, su actuación fue, en el primer caso, en contra de la gran rebelión y, en el segundo caso, a favor de la junta cuzqueña. Ello significa que ambos movimientos no tuvieron la misma naturaleza. Por lo menos, se infiere que, desde la óptica del cacique de Chinchero, se trató de eventos disímiles y, por lo tanto, adoptó posturas encontradas. En 1814, Pumacahua afirmó que la noticia del deceso del rey Fernando VII, comunicada por los Angulo antes de instalarse la junta cuzqueña, lo empujó a decidirse a "defender sus derechos" (O'Phelan, 1984, p. 69). ${ }^{34}$ Inclusive, el cacique de Chinchero repetía constantemente "notorio es que nuestro adorado Señor Don Fernando VII no existe en el día” (O’Phelan, 1984, p. 70), aunque, precisamente en 1814, Fernando VII retornaba al trono de España luego de su exilio en Valençay, Francia. Se deduce, entonces, que la presencia del rey Carlos III en el trono en 1780 fue una razón de peso para que Pumacahua se mantuviera al margen de los disturbios y, más bien, exteriorizara su lealtad al monarca. Además, estaba de por medio su consabida rivalidad con Túpac Amaru II, que lo convirtió en uno de los detractores del cacique rebelde.

Como lo hizo la nobleza inca del Cuzco en bloque, en 1780 Pumacahua también se mostró contrario a tener a la cabeza de una insurrección sin precedentes al "indio ordinario de Surimana” (O'Phelan, 2013, pp. 111-112), que era como la élite indígena cuzqueña se refería peyorativamente a Túpac Amaru, un cacique que no había sido confirmado en su cargo y que tampoco había logrado ingresar al exclusivo grupo de indios nobles que conformaban los Veinticuatro Electores del Cuzco (Cahill, 2003, pp. 18-22). ${ }^{35}$ Es más, sería

34 CDIP, tomo III. Lima, 1971, p. 310.

35 Sobre el tema, es de consulta obligada el libro de Donato Amado Gonzáles, El estandarte real y la mascapaycha. Historia de una institución inca colonial (2017, cap. V). 
precisamente Pumacahua quien se constituyó en el principal auxiliar de los realistas para orquestar la captura del cacique de Tinta y llevarlo ante las autoridades españolas, quienes, en abril de 1781, ordenaron su ejecución pública. Pumacahua recibió en retribución una medalla al mérito; así mismo, encabezó la lista de los caciques que mostraron su indiscutible lealtad a la Corona (Lewin, 1967: pp. 268, 395), por lo cual serían gratificados. La trayectoria del cacique de Chinchero siguió siendo fidelista, ya que en 1811 formó parte del ejército realista que acompañó al general arequipeño Manuel de Goyeneche a reprimir la segunda etapa de la insurgencia iniciada con la Junta de Gobierno de La Paz en 1809 (O’Phelan, 1984, pp. 63-64). ${ }^{36}$ Esto creó un precedente, ya que, cuando en 1814, se enviaron columnas militares a los territorios aledaños a la Junta del Cuzco con el propósito de incorporarlos, a Pumacahua se le ordenó dirigirse a la ciudad de Arequipa (Vargas Ugarte, 1958, p. 50), ${ }^{37}$ no al Alto Perú, donde su reputación era cuestionable, a causa de su sonada actuación fidelista en 1811.

Entonces, la presencia del cacique de Chinchero se dio en ambas coyunturas, pero mostró un comportamiento opuesto. Su activa participación en la junta cuzqueńa puede explicar por qué el nombre de Túpac Amaru no se invocó explícitamente en 1814: quedó silenciado por la enemistad que se habían profesado el cacique de Tinta con Mateo Pumacahua (Trouillot, 1995), ${ }^{38}$ quien ahora ostentaba el poder junto

36 Para mayores detalles, se puede consultar el artículo de María Luisa Soux, "La Paz en 1811 y 1814 en el contexto de una guerra continental", en el libro 1814: la Junta de Gobierno del Cuzco (O’Phelan, 2016, p. 468).

37 Pumacahua, junto con Vicente Angulo, llevó adelante la campańa a Arequipa.

38 Silenciar hechos y personajes siempre trae consigo una intencionalidad. La memoria de Túpac Amaru y su rebelión fue borrada durante la junta de 1814, porque, para la nobleza inca, dentro de la cual se situaba Puma- 
con los hermanos Angulo. Estaba, además, cercano el antecedente de haberse cuestionado al abogado Agustín Chacón y Becerra por haber mencionado a Túpac Amaru en una sesión del cabildo (Glave, 2001, p. 84), ${ }^{39}$ lo que le valdría estar en la mira de las autoridades peninsulares y ser ejecutado en abril de 1815 (Roedl, 2002, p. 112). Así, en 1814, no se repitió la figura de contar con un cacique en solitario a la cabeza de la dirigencia, como ocurrió en la gran rebelión, a pesar de seguir siendo el Cuzco, en el temprano siglo XIX, la cuna de los linajes incaicos (Garrett, 2005). El cacique de Chinchero, quien se encontraba en Urquillos (Vargas Ugarte, 1958, p. 48), ${ }^{40}$ fue convocado en 1814 en calidad de aliado, luego de ya haber sido conformada la junta cuzqueña, con los Angulo posesionados del mando central. Los hermanos Angulo -José, Mariano y Vicente- han sido a veces identificados como mestizos y otras, como criollos; sin embargo, actualmente existe consenso en aceptar que contaban con una posición económica acomodada, ${ }^{41}$ lo que cuestiona el calificar-

cahua, José Gabriel Condorcanqui era un cacique advenedizo y levantisco, al que habían derrotado y preferían no recordar.

39 Adicionalmente, Pumacahua no debe haber sentido mucho aprecio por Chacón y Becerra, en la medida en que este lo calificó de "bueno e inepto" durante la breve gestión del cacique de Chinchero como presidente de la Audiencia del Cuzco (Glave, 2001, p. 93).

40 Urquillos quedaba a unas dieciséis leguas del Cuzco.

41 En mi artículo "El mito de la independencia concedida", precisé que José Angulo era un hacendado en la doctrina de Abancay y arrendaba un molino en Quispicanchis; Vicente Angulo tenía alfalfares en Cuichipunco; y Mariano Angulo poseía la estancia Simatucca en Chinchero (1984, pp. 89, 90). Posteriormente, la investigación de Margareth Najarro, quien denomina a los Angulo "mestizos acaudalados", complementa esta información al indicar que tanto Mariano como Vicente Angulo estaban dedicados a la minería y que Mariano incluso era prestamista en La Paz y Vicente comerciaba con productos de Castilla y azúcar. Véase su artículo, "Constitucionalismo y revolución: Cuzco 1812-1814" en el libro 1814: La Junta de Gobierno del Cuzco (O’Phelan, 2016, pp. 151-154). 
los como "un puñado de hombres de bajísima extracción", referencia sesgada procedente de la Real Audiencia del Cuzco. ${ }^{42}$ En todo caso, el rol protagónico que le correspondió desempeñar al cacique de Tinta en 1780 no se volvió a dar durante la guerra de Independencia. Las juntas de gobierno van a estar integradas principalmente por criollos y mestizos que, como militares y abogados, escalarán posiciones sociales, mientras que los caciques no tendrán la misma preeminencia que obtuvieron en las rebeliones del siglo XVIII, y aún menos una figuración tan sobresaliente y emblemática como la que alcanzó Túpac Amaru II (O’Phelan, 1984, p. 91).

De este modo, la breve insurrección que lideró Francisco de Zela en 1811 en Tacna -de escasos cuatro días de duracióncontará principalmente con el apoyo de criollos locales, aunque también se buscará el respaldo del cacique Toribio Ara, quien estuvo acompañado por sus hijos (Seiner, 2013, p. 55). En el caso de la Junta de Huánuco de 1812, el apoyo indígena se materializó a partir de la masiva presencia de los alcaldes de indios que ejercieron presión al rodear la ciudad, y que mantenían un trato cercano con los curas doctrineros del territorio de frontera de los panataguas, ${ }^{43}$ quienes además de impartir el catecismo a la población nativa, eran lenguaraces (Chassin, 2006 y O'Phelan, 2016, pp. 295-297). En el Cuzco, como se ha indicado, fue el cacique Mateo Pumacahua quien colaboró con los hermanos Ángulo en la junta de gobierno de 1814,

42 Probablemente a partir de la opinión vertida por la Audiencia del Cuzco, Bonilla y Spalding califican a los Angulo de "mestizos y blancos pobres" (1981, p. 102).

43 El grupo étnico de los panataguas estaba conformado por indios de los pueblos de Santa María del Valle, Malconga, Acomayo, Panao, Pillao y Chichao. Al respecto, véase el artículo de Víctor Peralta, "La participación popular en las juntas de gobierno peruanas de Huánuco (1812) y Cuzco (1814)" en el libro Entre imperio y naciones. Iberoamérica y el Caribe en torno a 1810 (Cagiao y Portillo Valdés, 2012, p. 321). 
mientras que su yerno, Fermín Quispe Inga, fue nombrado justicia mayor del cercado del Cuzco. Para Pumacahua, como él mismo se encargó de señalar, estaba claro que se le necesitaba por su condición de cacique, que le daba la capacidad de movilizar a los indios de comunidad a favor de la junta (O'Phelan, 1984, p. 87). ${ }^{44}$ Sin embargo, adicionalmente, el cacique de Chinchero aprovechó astutamente su posición de poder al lado de los Angulo para conseguir el nombramiento como subdelegado interino de Calca para su hijo Mariano García Pumacahua (Iberico, 2016, p. 283), un cargo político creado como parte del sistema de intendencias implementado en el Perú en $1784 .{ }^{45}$ De esta manera, se constata que la junta cuzqueña respetó el andamiaje político montado por los borbones, donde el subdelegado pasó a reemplazar al corregidor.

En este sentido, vale recordar las declaraciones del cacique Pumacahua antes de ser ejecutado en Sicuani, en 1815; en estas, expresó de forma categórica que, durante el funcionamiento de la junta cuzqueña, no había utilizado la indumentaria propia de los incas, sino que siempre había vestido en el campo de batalla su uniforme de brigadier general (O'Phelan, 2014, p. 321), con el cual incluso se hizo retratar en calidad de donante ${ }^{46}$ (véase la imagen 5). Parece ser, en-

44 Se recomienda también consultar el artículo de Nuria Sala i Vila, "La participación indígena en la rebelión de Angulo y Pumacahua, 18141816 " en el libro Conquista y resistencia en la historia de América (García Jordán et ál., 1992).

45 Sobre el establecimiento del sistema de intendencias en el Perú, véase el libro de John Fisher, Government and Society in Colonial Peru. The Intendant System, 1784-1814 (1970).

46 En el mencionado cuadro, en la parte inferior derecha, aparece Pumacahua, quien luce su uniforme militar; en la parte inferior izquierda, está su esposa, con un escapulario de la virgen del Rosario en el pecho. Al centro del lienzo, se ubica Polonia, la hija de ambos, quien viste el hábito de monja de velo negro después de haber profesado en el convento de Santa 
tonces, que el cacique de Chinchero no se prestó para que, en su persona, se recreara la imagen del inca. Inclusive, de acuerdo con la confesión de Diego Diez Feijoó, cuando Vicente Angulo intentó introducir entre sus títulos el de "Apoderado de los Antiguos Incas del Perú", encontró resistencia de parte de sus seguidores y tuvo que desistir de esta idea (O'Phelan, 1984, pp. 70-71). Por lo tanto, la superposición de imágenes que se dio entre algunos pobladores indígenas durante la gran rebelión, en la que Túpac Amaru resultaba indistinto de la figura del Inca, no funcionó con igual fuerza en 1814. Para ese momento, quien podría haber aludido a esta identificación habría sido el cacique Mateo Pumacahua, aunque para él -como se observa- la graduación militar que había logrado alcanzar pareció resultarle más conveniente. No hay que olvidar que, después de la gran rebelión, se incentivó la militarización de los caciques (O’Phelan, 1997, p. 34) ${ }^{47}$ ante el notorio declive y descrédito que experimentó la institución cacical a finales del siglo XVIII, al ponerse en entredicho con la Corona, pues una facción de ellos apoyó al cacique rebelde (O'Phelan, 1997, pp. 34-35). Volviendo al caso de Pumacahua, da la impresión que la política de emular las graduaciones militares entre los indios nobles estaba ganando adeptos. ${ }^{48}$ Además, hasta ese momento, ser brigadier general

Teresa, reservado para doncellas espańolas y criollas. La advocación que presenta el cuadro es santa Cecilia, quien toca el órgano.

47 En términos de una política general, Gabriela Tío Vallejo y Víctor Gayol consideran que la militarización aparece como una variable fundamental del proceso de transición política de las primeras décadas del siglo XIX. Coincide cronológicamente, entonces, con la primera fase de las guerras de independencia, la de las juntas de gobierno. Para mayor detalle, véase su artículo, "Hacia el altar de la patria. Patriotismo y virtudes en la construcción de la conciencia militar entre las reformas borbónicas y la revolución de independencia”, en el libro Fuerzas militares en Iberoamérica. Siglos XVIII y XIX (Ortiz, 2005, p. 112).

48 Este será también el caso de Marcos García Chillitupa, quien, como Pu- 


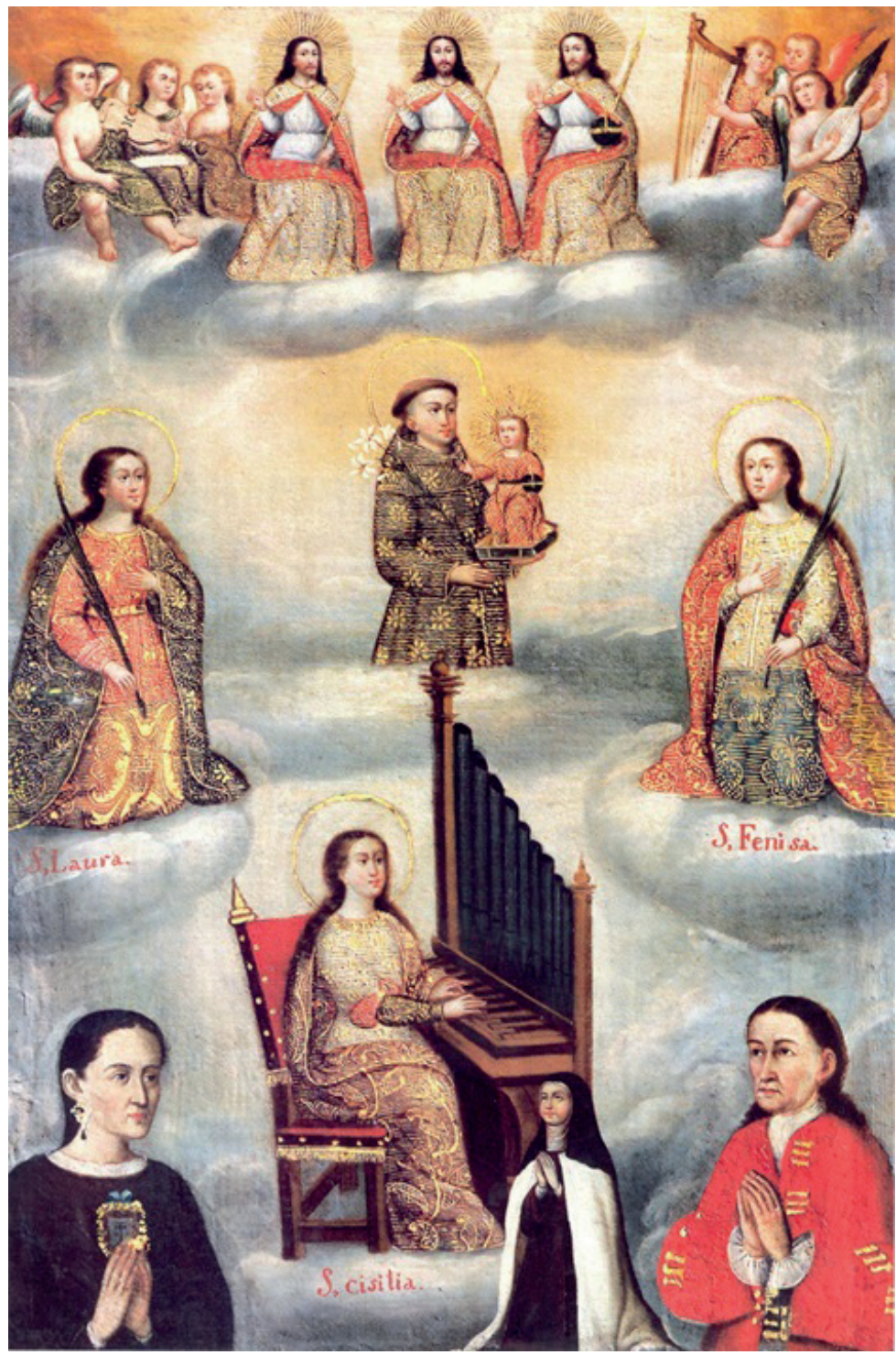

Imagen 5. Cacique de Chinchero Mateo Pumacahua como donante. Óleo sobre lienzo, anónimo. Museo Regional del Cuzco En: Scarlett O’Phelan Godoy, Mestizos reales en el virreinato del Perú, p. 65. 
era un honor que se había reservado para peninsulares y criollos; el caso de Pumacahua era, a todas luces, la excepción a la regla.

Si hay algo en común entre la insurrección de Zela de 1811 y la Junta de Huánuco de 1812, es que, en ambos movimientos, se alude a la figura del abogado bonarense Juan José Castelli; de esta manera, los conatos subversivos en territorio peruano se conectan con la Revolución de Mayo de 1810 en el Río de la Plata. En el caso de Tacna, la derrota de Castelli en Huaqui frente al ejército realista de Goyeneche será el golpe de gracia para disolver el incipiente alzamiento de Zela (Wasserman, 2013, pp. 298-299), ${ }^{49}$ lo que puso en evidencia la cercanía no solo económica, sino también política entre Tacna, Arica y el Alto Perú. En relación con la Junta de Huánuco, se difunde el rumor de la venida del Inca Castelli, cuyo artífice bien pudo haber sido el presbítero Bartolomé Larrea, quien se jactaba de ser capitán de Castelli y tener cartas escritas por él. ${ }^{50}$ Lo cierto es que la alusión a Castelli proviene de la declaración que realizó Manuel Zabala en Tarma el 3 de marzo de 1812, en la que puntualmente especificó "que ya venía el hijo del Inca y que Castelli tenía razón" ${ }^{51}$ En ningún momento afirmó que Castelli era el hijo del Inca o el propio

macahua, en 1780 se comportó como un acérrimo realista, por lo cual fue nombrado teniente coronel de las ocho parroquias del Cuzco; para 1812, era aún teniente coronel. Consúltese, al respecto, el libro de David Cahill, From rebellion to independence in the Andes: soundings from southern Peru, 1756-1830 (2002, pp. 113-114).

49 El militar gallego Andrés García Gamba se refiere a los "chispazos revolucionarios que estallaron en Arequipa y Tacna" cuando se tenía a Castelli por vencedor, antes del desastre de Huaqui.

50 CDIP, tomo III, vol. 2, 1971, p. 25. De acuerdo con la declaración del español José Bodelón, el presbítero Bartolomé Larrea decía que era capitán de Castelli y tenía cartas escritas por él.

51 CDIP, tomo III, vol. 2, 1971, p. 25. 
Inca. Es aceptado que el rumor puede desvirtuar o tergiversar la información inicial al propagarse, ${ }^{52}$ como parece haberse dado en este caso. No obstante, hay que aclarar que para ese momento Castelli se encontraba sometido a un proceso judicial de carácter político y militar en Buenos Aires, durante el cual falleció, en octubre de 1812 (O’Phelan, 2016, p. 299)..$^{53}$

La Junta del Cuzco también buscó en 1814 acercarse a la Junta de Buenos Aires, para lo cual José Angulo nombró apoderados y plenipotenciarios ante las Provincias Unidas del Río de la Plata. Los designados para esta representación oficial fueron el clérigo Francisco Carrascón, prebendado de la iglesia del Cuzco, y el cura de Yaurique, Paruro, Juan Alberto Mendieta; ambos eclesiásticos contaban con el beneplácito del obispo del Cuzco, Pérez de Armendáriz (Vargas Ugarte, 1958, p. 49). Angulo acotaría más adelante que, mientras Abascal había desconocido a la junta cuzqueña invitándolos a deponer armas, Manuel Belgrano -quien se encontraba en campaña en el Alto Perú- los había congratulado a nombre de la Junta del Río de la Plata (Bushnell, 1988, p. 121). ${ }^{54}$ En consecuencia, de ahí en adelante, Angulo se referiría al

52 Sobre el tema del rumor en la historia, véase el libro de Jean-Nöel Kaperer, Rumores. El medio de difusión más antiguo del mundo (1989). Para el estudio del rumor conectado con el miedo, véase el libro de Delumeau, El miedo en Occidente. Siglos XIV-XVIII. Una ciudad sitiada (2002, p. 276).

53 La información procede de la Colección documental de la independencia del Perú (CDIP), tomo III, vol. 2, 1971, p. 25, "La Revolución de Huánuco, Panataguas y Huamalíes de 1812", estudio introductorio de Ella Dunbar de Temple. Sobre Castelli, se puede consultar el libro biográfico de Fabio Wasserman, Juan José Castelli. De súbdito de la Corona a líder revolucionario (2011, p. 237).

54 En 1813, los patriotas del Río de la Plata retomaron la campaña hacia el Alto Perú, esta vez bajo la dirección de Manuel Belgrano, quien eventualmente sería derrotado por Pezuela en 1815. 
virrey Abascal como "el marqués de la Discordia" (Vargas Ugarte, 1958, p. 49) (véase la imagen 6). Al respecto, Brian Hamnett considera que la junta cuzqueña tuvo un carácter separatista, de ahí que buscara el apoyo de los insurgentes de Buenos Aires (Hamnett, 2013, p. 42), tendencia que probablemente se hizo más radical luego del desencuentro que se suscitó entre los Angulo y el virrey, quien combatió tenazmente la junta. En todo caso, es un hecho que la Junta del Cuzco buscó interlocutores en el Alto Perú y Buenos Aires, mientras que el envolvimiento de la región norte en los acontecimientos del sur andino fue absolutamente marginal, por no decir prácticamente inexistente (Cahill, 2011, p. 215).

\section{De soldados de Dios a soldados de la patria}

Si bien la evidencia demuestra que se produjo una deserción significativa de parte de los criollos que acompañaron inicialmente al cacique de Tinta, luego de la "victoria" de Sangarará -como la denominaban los seguidores de Túpac Amaru- o de los "horrores" de Sangarará -en el imaginario de los realistas,$-{ }^{56}$ hubo un grupo de clérigos criollos que decidieron permanecer al lado del cacique rebelde; varios de estos habían estado presentes en la ejecución del corregidor Antonio de Arriaga con el fin de garantizar que tuviera una "buena muerte" (O’Phelan, 1995, pp. 111112 y O’Phelan, 2012a, p. 265). ${ }^{57}$ Entre ellos, destaca ní-

55 Los detractores de Abascal lo criticaban por haber sido nombrado virrey del Perú durante el período de influencia del favorito Godoy. Al respecto, véase el libro de Patricia H. Marks, Deconstructing Legitimacy. Viceroys, Merchants and the Military in Late Colonial Peru (2007, p. 155).

56 AGI Audiencia de Lima, leg. 1052. Se alude a que, después de Sangarará, hubo muchos españoles que "desampararon" al cacique rebelde, desertando de sus filas.

57 Entre los clérigos que ayudaron a "buen morir" al corregidor, estuvieron el cura de Pampamarca, Antonio López de Sosa, e Ildefonso Bejarano, ayudante de Pampamarca, cacicazgo de Túpac Amaru. También apoya- 


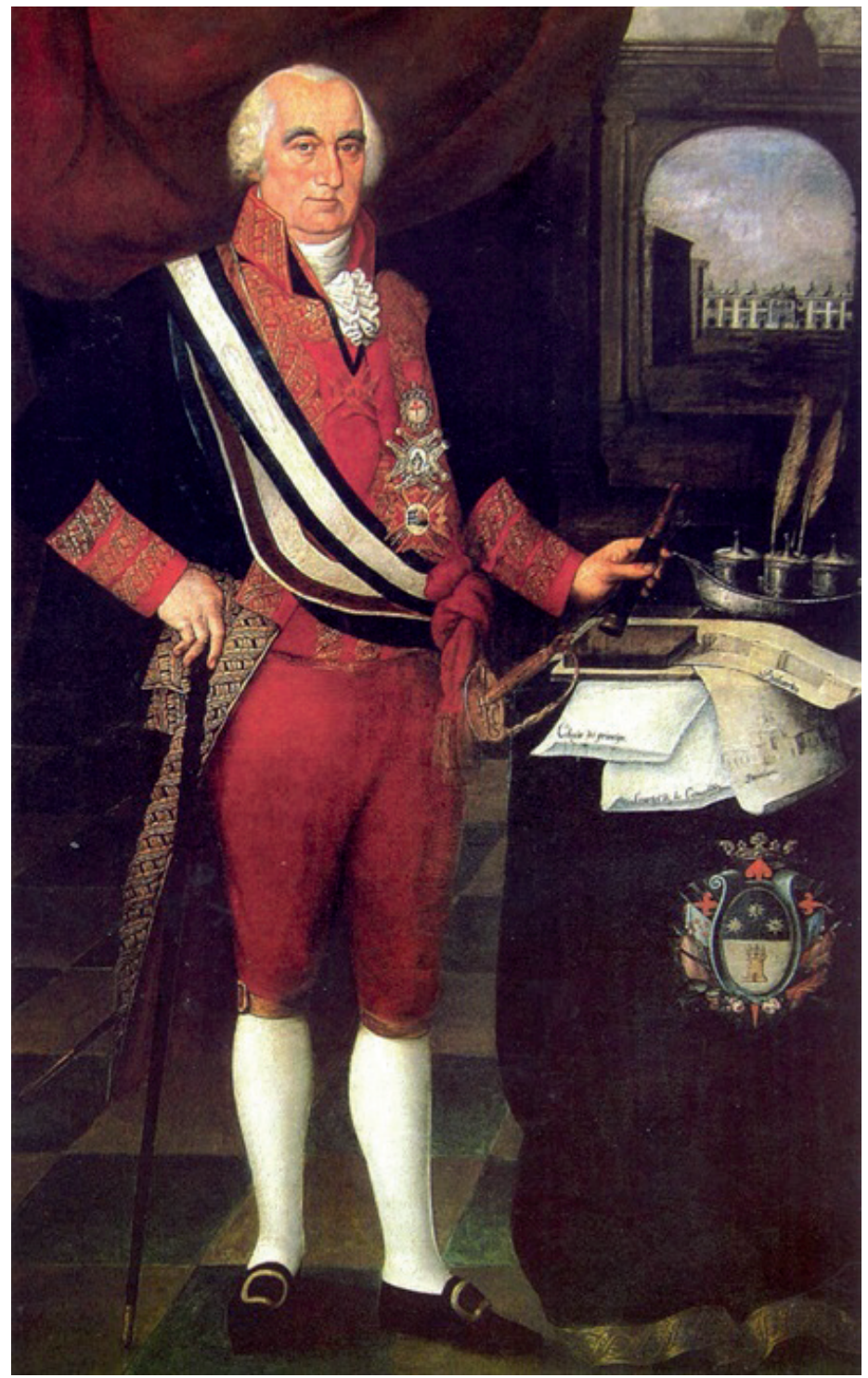

Imagen 6 José Fernando de Abascal, virrey del Perú. Óleo sobre lienzo de Pedro Díaz. Colección Galería de Virreyes. Museo Nacional de Arqueología, Antropología e Historia del Perú, Lima 
tidamente el panameño Antonio López de Sosa, cura de Pampamarca, quien se decía compadre de Túpac Amaru por haberlo casado y haber bautizado a sus hijos, quien le facilitó, además, préstamos de dinero (O'Phelan, 2012a, pp. 266-267). Otro de los inculpados, José Maruri, cura de Asillo, Azángaro, fue más allá de su labor pastoral al remitir remesas de plomo y pólvora, insumos requeridos para el mantenimiento de las armas de los rebeldes; en su casa, se halló una copiosa correspondencia que había intercambiado con Túpac Amaru, la cual denunciaba su complicidad (L. E. Fisher, 1966, p. 113). Estos clérigos procesados por sedición serían también los encargados, junto con los escribanos criollos, de redactar manifiestos y proclamas que contribuyeron al sustento ideológico de la insurrección; sus escritos destacaron por estar "plagados de citas bíblicas", como de manera aguda hizo notar posteriormente el visitador Areche. ${ }^{58}$ Además, varios de ellos se aprovecharon de la cobertura que les brindaba el hábito monacal para actuar como informantes o espías.

Inclusive, a instancias del obispo del Cuzco, el arequipeño Manuel Moscoso y Peralta, se promovió que los clérigos leales a la Corona se organizaran para prestar apoyo a las tropas realistas. Así, el cura de Coasa, Antonio Valdez, se ofreció a comandar una columna destinada a resguardar el puente de Urubamba, que se consideraba un punto estratégico en la defensa de la ciudad del Cuzco. Igualmente, el cura de Chinchaypuquio, Abancay, Martín Mariano Toledo, reclutó a su feligresía para fijarla como guardias y centinelas de los

ron al cacique rebelde Gregorio Yépez y Justo Gallego, ambos asistentes de Caccha, además de otros clérigos de las doctrinas inmediatas.

58 Museo Británico, Londres. Egerton 1218. Correspondencia del visitador José Antonio de Areche. Véase también el libro de Boleslao Lewin, La rebelión de Túpac Amaru (1967, p. 238) y el libro de Lillian Estelle Fisher, The Last Inca Revolt, 1780-1783 (1966, p. 113). 
puentes de Churuc y Cutuctay, de forma que bloqueaba su entrada. (Garzón Heredia, 1996, pp. 251 y 255).

Así como un grupo de clérigos jugó un papel relevante apoyando la gran rebelión -pues sus miembros preparaban los pronunciamientos o actuaban como espías y centinelas- también le correspondió tener una actuación destacada en el temprano siglo XIX al respaldar, desde el púlpito e incluso empuñando las armas, a las juntas de gobierno de Huánuco y Cuzco. En estos casos, sus discursos defendieron el autogobierno en ausencia del rey, atacaron a las autoridades peninsulares prepotentes y corruptas, y avalaron las propuestas reivindicativas de la Constitución Liberal, para lo cual se convirtieron en soldados de la patria sin temor de marchar al frente. En este sentido, es notable el caso del cura tucumano Ildefonso Muñecas, quien se involucró en la Junta de La Paz de 1809; más adelante, fue un fervoroso activista en la Junta del Cuzco de 1814 y encabezó la columna militar que enviaron los hermanos Angulo a Puno y a La Paz (Vargas Ugarte, 1958, p. 53), a la que se unieron en su avance numerosos indígenas del altiplano (Soux, 2016, p. 468). Es entonces posible observar que, en el contexto de las juntas de gobierno, los clérigos portaron armas y enfrentaron batallas; no en vano la Audiencia del Cuzco los acusó de "haber sido caudillos de tropas [...]".59 Esto se diferencia de lo ocurrido en la gran rebelión (Walker, 2014, p. 83), en la que los eclesiásticos colaboradores de Túpac Amaru actuaron fundamentalmente como capellanes o confesores, tratando de mantenerse al margen del enfrentamiento bélico; se aduce que, en cambio, los sacerdotes del bando realista cruzaron esta línea e ingresaron, aparentemente, en el terreno militar de la organización de las tropas para enfrentar al cacique rebelde (Garzón Heredia, 1996, p. 247). ${ }^{60}$

59 CDIP, tomo III, vol. 7. Lima, 1972, p. 607.

60 El autor señala que el cura Juan Carlos García fue comandante de una 
La crisis por la que atravesó el sistema cacical desde mediados del siglo XVIII, producto de la adulteración en el nombramiento de caciques, creó fisuras y distanciamiento en la relación entre las comunidades indígenas con sus tradicionales autoridades étnicas -los kurakas o caciques-, quienes cada vez les resultaban menos representativos y más perniciosos. El cabildo indígena, de alguna manera, suplió este vacío mediante la figura de los alcaldes de indios (O'Phelan, 1997, p. 54). Sin embargo, al ser el cargo anual y, por lo tanto, la gestión del alcalde breve, los curas doctrineros también comenzaron a asumir el papel de interlocutores y voceros de las comunidades, ${ }^{61}$ lo cual puede explicar su notoria presencia en las juntas de gobierno de Huánuco y el Cuzco. No hay que olvidar que, además, estos clérigos hablaban quechua o aymara (O'Phelan, 1995 , p. 55 y O'Phelan, 2013, p. 143), con lo cual la aceptación y confianza de parte de las comunidades hacia ellos era predecible. Además, la presencia del cura doctrinero al servicio de un poblado o una provincia podía prolongarse por varios ańos, lo que daba continuidad a su gestión.

En el caso de la Junta de Huánuco de 1812, se han identificado a los criollos Domingo Berrospi, quien fue aclamado

tropa compuesta por la feligresía de la provincia de Cotabambas, Cuzco. Por otro lado, en el informe a SM de méritos y servicios, don José Eduardo Pimentel, coronel de milicias, argumentó que en enero de 1781 comandó las divisiones de tropas de Cotabambas y Andahuaylas, y que se formó el ejército que operó contra el insurgente de las provincias rebeldes, hasta someterlas a la debida obediencia (Archivo Regional del Cuzco, ARC, Real Audiencia. Causas Ordinarias, leg. 2, año 1789). Por lo tanto, Cotabambas sí contó con una columna militar.

61 David Cahill aborda también el tema de los curas doctrineros en su artículo "Curas and Social Conflict in the Doctrinas of Cuzco, 1780-1814" (1984). Por ejemplo, en 1792, el cura de Maras, Manuel del Castillo, acusó al cacique Agustín Núńez de agraviar a los indios (ARC Real Audiencia. Causas Ordinarias, leg. 10, año 1792). 
como subdelegado, y a Juan José Crespo y Castillo, nombrado síndico procurador como los principales dirigentes (Vargas Ugarte, 1958, p. 35); sin embargo, lo cierto es que no se le ha dado la importancia que merece al papel que jugaron los clérigos involucrados en la insurrección desde el inicio, y que se constituyeron en la pieza clave para coordinar la movilización de los indios panataguas, cuya invasión a la ciudad provocó el temor y la huida de los peninsulares.

Así, entre los clérigos regulares que participaron del conato del 22 de febrero, se encontraba Marcos Durán Martel, un agustino originario de Huánuco, quien se convirtió en la figura central del movimiento, por lo que fue identificado como el autor intelectual de la revolución y "el capitán de los alzados" (Klaiber, 2001, p. 130). Otros de los implicados fueron el mercedario natural de Quito, Mariano Aspiazu; el también mercedario natural de Lima, Francisco Ledesma; e Ignacio Villavicencio, un agustino cuzqueño de 43 años, maestro de novicios. Se les acusó de haber redactado pasquines, décimas, proclamas y órdenes subversivas en español y quechua, y distribuirlas entre la población arengando a los indios a tomar la ciudad y expulsar a los europeos (O'Phelan, 2016, p. 298). Si bien en la Junta de Huánuco el nombre de Castelli tuvo resonancia, por otro lado, a través del clérigo quiteño Mariano Azpiazu, se estableció comunicación con la Junta de Quito, en la que Azpiazu se había visto envuelto, lo cual le había valido la expulsión (O’Phelan, 2016, p. 299). En este sentido, la junta huanuqueña estuvo conectada tanto con los acontecimientos insurgentes del sur como con los del norte y en ambos casos fueron clérigos los que sirvieron de enlace.

La junta quiteña de 1809-1812 estuvo presidida, en su segunda etapa, por el obispo de Quito, el criollo caleño José Cuero y Caicedo. A pesar de que, en el norte del virreinato peruano, como Piura, Lambayeque, Trujillo y Cajamarca, no 
se instalaron juntas de gobierno -tema pendiente de estudio-, clérigos de Piura y de Lima brindaron su apoyo a la Junta de Quito, siendo uno de ellos acusado de "insurgente seductor" (O’Phelan, 2014, p. 63). ${ }^{62}$ La presencia del obispo Cuero y Caicedo, sin duda, se prestó para convocar a muchos seguidores dentro del sector eclesiástico.

En relación con la revolución del Cuzco, se inculpó a Juan Angulo, el hermano clérigo de José Angulo, de haber abandonado a su feligresía para apoyar a la junta de gobierno con sus "infames consejos". ${ }^{63}$ Esto lleva a pensar que quizá no fue solo el respaldo del obispo Pérez Armendáriz, aliado incondicional de Francisco Carrascón, sino también la activa presencia del sacerdote Juan Angulo lo que explique el soporte proporcionado por el bajo clero a la junta cuzqueña. Así lo demuestra la docena de curas doctrineros de poblados adyacentes al Cuzco que favorecieron abiertamente la revolución de los Angulo (Eguiguren, 1914, p. 111). ${ }^{64}$

De acuerdo con el estudio de María Consuelo Sparks, entre 1810 y 1814 , los nombres de 62 clérigos quedaron registrados por haber estado envueltos en actividades subversivas en el virreinato del Perú. De ellos, 28 eran miembros del clero regular y 36, del secular; sus parroquias estaban situadas en Cuzco, Huánuco, Arequipa, Tacna y Lima. No es casual que las cuatro primeras ciudades hubieran experimentado conatos insurreccionales de envergadura entre las fechas señaladas

62 Los clérigos involucrados fueron Domingo Renxifo y Manuel Guisado, limeños, y José Antonio Mena, piurano, descrito como "insurgente seductor".

63 CDIP, tomo III, vol. 8. Lima, 1974, p. 196.

64 De acuerdo con el autor, los curas de Andaguaylillas, Accha, Pitahuasi, Hurocondo, Chelahuanca, Soraya, Huaquilca, Tapairihua, Chinchaypuquio, Pantipanti, Yucay y Checacupe simpatizaron con la insurrección (citado en O'Phelan, 1984, p. 77). 
(Sparks, 1972, p. 234). Tampoco debe extrañar que, entre los insurrectos, se registrara un mayor número de miembros del clero secular, pues estos tenían menos restricciones que el clero regular para participar en forma activa de la vida cotidiana de las ciudades, por lo que podían departir y entremezclarse con sus habitantes (Ganster, 1986, p. 161).

Los clérigos que tuvieron una incuestionable visibilidad como insurgentes fueron amonestados e incluso ejecutados. En el caso de la Junta de Huánuco, fray Marcos Durán Martel fue condenado a servir diez años en un hospital de España (Vargas Ugarte, 1958, p. 38). Por su parte, a causa de su participación en la junta cuzqueña, Ildefonso Muñecas encontró la muerte en 1816, cuando era conducido cerca del Desaguadero, hecho que levantó sospechas de haber sido asesinado. Por su parte, el clérigo José Gabriel Béjar, quien estuvo a la cabeza de la columna militar enviada por los Angulo a Huamanga, fue ejecutado en el Cuzco en 1815 (Klaiber, 2013, p. 78). El ajusticiamiento al que se sometió a algunos clérigos revolucionarios en la coyuntura de las juntas de gobierno no se observa en el caso del movimiento de Túpac Amaru, en el que, a lo sumo, fueron procesados y desterrados. Ello quiere decir que, para la primera fase de la independencia, las confrontaciones fueron más violentas y menos toleradas, quizá porque los clérigos llegaron al extremo de empuñar las armas y liderar tropa, es decir, se extralimitaron en el cumplimiento de sus funciones eclesiásticas.

Con el propósito de fortalecer la monarquía, los borbones trataron de disminuir el poder y la influencia que venía ganando la Iglesia, para lo cual tomaron algunas medidas consideradas drásticas, como la expulsión de los jesuitas en 1767 y la extinción de la orden en 1773 (Callaham, 1989, p. 35); ;5 el plan de reducción del número de miembros de las órde-

$65 \mathrm{El}$ autor considera que la expulsión fue instigada por la Corte española. 
nes religiosas (Cortés Peña, 1989, pp. 77, 96 y 113);66 y la secularización de las doctrinas decretada en 1749 para las diócesis de México y Perú (Brading, 1994, p. 62). ${ }^{67}$ Además, se les imputó estar inclinados a favorecen a los candidatos peninsulares en los concursos de méritos para la asignación de altos nombramientos, como obispos o arzobispos (Ganster, 1986 p. 147), en detrimento de los aspirantes criollos y más aún, de los mestizos. Salvo el caso excepcional del prebendado peninsular Francisco Carrascón, los clérigos que se mostraron proclives a las juntas de gobierno y que se involucraron en ellas fueron fundamentalmente criollos y mestizos. Buscaban, sin duda, tener más presencia y peso dentro de las instituciones influyentes de la Iglesia, de las cuales se sentían postergados, situación que se haría menos sostenible luego de ser declarados "españoles-americanos" con igualdad de derechos. Como señalaba Baquíjano y Carrillo en un informe remitido al rey en 1814: "la exclusión practica[da] de todos los empleos de honor, comodidad y distinción, es el agravio de que más se quejan los americanos, y que exige también una cuidadosa atención” (Durand Flórez, 1985, p. 155). ${ }^{68}$

66 Durante el reinado de Carlos III, se produjo una disminución del número de religiosos de las órdenes, como lo demuestra el censo de Floridablanca y los documentos confeccionados por los mismos superiores de las órdenes.

67 En 1753, el decreto se hizo extensivo a todas las diócesis de la América española. Así, en menos de una década, franciscanos, dominicos y agustinos perdieron numerosas parroquias. En el artículo de Jesús Izquierdo et ál., "La reforma de regulares durante el reinado de Carlos III. Una valoración a través del ejemplo madrileño" -en el libro Carlos III, Madrid y la Ilustración (Equipo Madrid de Estudios Históricos, 1988, p. 219)-, se señala que al clero secular se le otorgaron poderes para controlar el comportamiento de los feligreses.

68 Las cursivas son de la autora. 


\section{Territorialidad e insurgencia: el norte frente al sur}

Se puede observar que la gran rebelión fue un movimiento de masas sin precedentes que se concentró en el sur andino del virreinato del Perú, y se expandió al Alto Perú (Audiencia de Charcas), que desde 1776 formaba parte del virreinato del Río de la Plata ${ }^{69}$ No obstante, habiendo sido reciente la transferencia del territorio altoperuano a Buenos Aires, y teniendo una larga tradición de más de tres siglos de haber funcionado articulados el Bajo con el Alto Perú, en 1780 el sur andino se comportó como un espacio integrado, como una unidad sincronizada (O'Phelan, 2012a, pp. 301 y 312). De hecho, tuvo la capacidad de gestar una insurrección que puso en jaque a las autoridades peninsulares, quienes la calificaron de "sublevación general".

Si bien fue palpable el eficiente engranaje que se dio entre al Bajo y el Alto Perú durante el alzamiento, sin duda el que José Gabriel Túpac Amaru fuera dueño de una importante empresa de arrieraje, negocio del cual participaba su familia y con el que cubría por lo menos un par de veces al año la ajetreada ruta de Cuzco a Potosí, contribuyó a ello (O’Phelan, 2012a, p. 258). ${ }^{70}$ Así, en abril de 1779, Diego Cristóbal Túpac Amaru había trasportado productos a Potosí y, en diciembre del mismo año, el propio José Gabriel había llevado mercadería a Oruro. En abril de 1780, a escasos seis

69 Sobre el tema de la creación del virreinato del Río de la Plata, véase el libro de John Lynch, Spanish Colonial Administration, 1782-1810. The Intendant System in the Viceroyalty of the Rio de la Plata (1958). También es de importancia la publicación de Guillermo Céspedes del Castillo, Lima y Buenos Aires, repercusiones económicas y politicas de la creación del virreinato del Plata (1947).

70 Los parientes de Túpac Amaru involucrados en la empresa de arrieraje del cacique eran Diego Cristóbal Túpac Amaru, Francisco Túpac Amaru, Juan Túpac Amaru, Francisco Noguera y Pedro Mendigure. 
meses de que estallara la gran rebelión, el "cacique arriero" viajó a Cochabamba y Oruro transportando textiles de obrajes (O’Phelan, 1995, p. 93). Está demás decir que este era un circuito comercial que el cacique conocía a fondo y en cuyo trayecto debió haber forjado varios contactos. De ahí, posiblemente, que ya en plena campaña militar, al tener que decidir si ocupaba el Cuzco o avanzaba al Alto Perú, se decantó por esta segunda opción, donde, al parecer, ponía en menor riesgo el éxito de la gran rebelión. Intentar avanzar hacia la ciudad del Cuzco, que estaba guarnecida por los realistas luego de haberse debelado la conspiración de plateros en abril de 1780, seguida de un juicio, no era la opción más segura (Angles, 1975, pp. 62-95). ${ }^{71}$ De hacerlo, habría puesto en peligro la estabilidad del movimiento.

Un hecho que resulta sorprendente es comprobar que los ecos de la gran rebelión no tuvieron mayor resonancia en el norte del virreinato del Perú, concretamente en el obispado de Trujillo. ${ }^{72}$ Esta falta de empatía pone en evidencia que el norte y el sur no mantenían una comunicación fluida y revela su poca interacción; incluso, permanecieron desconectados en un contexto de intensa agitación social, como el que se produjo durante la sublevación general de 1780-1781 (O’Phelan, 2019, p. 410). Mientras el Bajo Perú miró de inmediato hacia su vecino y contraparte, el Alto Perú, da la impresión que no entró en diálogo con el norte, como si se tratara de un territorio externo a sus propios intereses y objetivos, más allá del alejamiento geográfico que los separaba.

71 BNP. Las copias del juicio completo se encuentran en los expedientes C418, C419 y C420.

72 En mayo de 1779, Baltazar Jaime Martínez Compañón se convirtió en el nuevo obispo de Trujillo. Es decir, estaba en funciones cuando ocurrió la gran rebelión en el surandino. Al respecto, véase el libro de Emily Berquist Soule, The Bishop's Utopia. Envisioning Improvement in Colonial Peru (2014, cap. 2). 
En el caso de la sierra central, el comportamiento fue diferente, pues demostró tener una mayor conexión con el sur andino, si bien esta no se activó durante la gran rebelión. No obstante, en 1783, una oleada insurgente se hizo sentir en la provincia de Huarochirí, ubicada en la sierra de Lima, conocida por mantener una estrecha relación con la capital. Es interesante constatar que esta proyectada asonada se descubrió precisamente al mes siguiente de que Diego Cristóbal Túpac Amaru, quien se había acogido al indulto real del 26 de enero de 1782 (Lorandi y Bunster, 2013, p. 114), -denominado "falsa amnistía" por Ignacio de Castro-, ${ }^{73}$ fuera ejecutado en la plaza del Regocijo del Cuzco, el 31 de mayo de 1783 , acusado de conspiración por parte de las autoridades peninsulares, que siempre lo tuvieron en la mira (Walker, 2014, pp. 245-246). Eliminar al último miembro de la estirpe de los Túpac Amaru era un objetivo que los funcionarios reales se habían trazado y que, con el afán de ganar tiempo, disfrazaron con el ofrecimiento del indulto.

Es probable que la noticia del ajusticiamiento de Diego Cristóbal llegara a Huarochirí, donde además ya debían saber de su captura. En este sentido, vale recordar que la ruta de arrieraje de esta provincia era de alto tránsito y en el tramo del Camino Real que cubría las provincias de Jauja, Huamanga y Cuzco, hacía escala en Tinta o Canas y Canchis, cacicazgo de José Gabriel Túpac Amaru. ${ }^{74}$ De ahí que hubiera un fluido contacto entre Cuzco y Huarochirí antes y después de la gran rebelión. Esta afirmación se verifica con la declaración que realizó, en abril de 1781, Diego Ortigoza, el arequipeño que se desempeñaba como tutor de los hijos del cacique de Tinta,

73 Ignacio de Castro, en su Relación del Cuzco, cuestiona la transparencia del indulto, que, como luego quedó demostrado, fue solo una estratagema (Ignacio de Castro, Relación del Cuzco. Universidad Nacional Mayor de San Marcos, 1978, p. 62, pie de página 1).

74 Museo Británico, Londres. Additional (ms.) 17,587. 
quien acotó, "que oyó decir a la mujer del rebelde, después que se ahorcó al corregidor [Arriaga], que todos estaban prevenidos por su marido desde Huarochirí, para acompañarlo en la empresa [...] para que saliera bien lo que intentaba" ${ }^{75}$ Pero este esperado apoyo de parte de Huarochirí no se materializó en 1780, y demoró en hacerse efectivo prácticamente tres ańos y, cuando en 1783 se estaba poniendo en marcha, fue abortado.

Así, en el mes de junio de 1783, se delató que se estaba fraguando en Huarochirí un movimiento subversivo, que el indio noble Felipe Velasco Túpac Inga Yupanqui había venido organizando. Este, al momento de ser capturado, contaba con treinta años de edad, era descrito como mestizo ${ }^{76}$ y había fijado su residencia en Lima, donde se desempeńaba como ensamblador de espejos (Sala i Vila, 1995, p. 279). De esta manera, Túpac Inga Yupanqui mantenía vínculos con Huarochirí, que sin duda reforzaba con periódicas visitas, pero también tenía contactos en el Cuzco, que seguían activos. De acuerdo con el proceso judicial que se llevó a cabo luego de desbaratarse la conspiración, Felipe Velasco "decía ser hijo de Juan Velasco Inga Yupanqui y de doña Gregoria Túpac Amaru", quienes, a su vez, eran cuzqueños. ${ }^{77}$ Es decir, la calidad de indio noble le venía por el lado de ambos progenitores y, por línea materna, se vinculaba con el linaje de los Túpac Amaru; de ahí se explica que declarara ser pariente del cacique de Tinta.

Según los testimonios, la conmoción empezó en el pueblo de la Ascensión y se expandió posteriormente a otros poblados de la provincia de Huarochirí por lo que se llevaron a cabo,

75 AGI. Audiencia de Lima, leg. 665. Confesión de Diego Ortigoza. Las cursivas son de la autora.

76 AGI. Audiencia de Lima, leg. 663, citado en O’Phelan (2012b, p. 699).

77 AGI. Audiencia de Lima, leg. 663, citado en O'Phelan (2012b, p. 700). 
de acuerdo con la causa criminal, "juntas clandestinas y sediciosas conspiraciones". ${ }^{78}$ Se puede inferir que el complot de la rebelión planeada por Velasco Inga Yupanqui atravesó por dos momentos: en una primera instancia, Velasco buscó el apoyo de los parientes de Túpac Amaru que se encontraban presos en Lima -Mariano Bastidas y Andrés Mendigure-; sin embargo, al dificultarse esta gestión, en un segundo momento, se decidió a llevar adelante la sublevación solo, pero bajo la égida de Túpac Amaru (O'Phelan, 2012b, p. 700). Entonces, el territorio que cubrió la gran rebelión fue fundamentalmente el Bajo y el Alto Perú, y hubo un conato rebelde en Huarochirí, en 1783, en la medida en que había puntos de encuentro entre Huarochirí y Cuzco gracias a la transitada ruta de arrieraje que los unía; a ello se sumaba que una rama de parientes del cacique de Tinta se había establecido en Huarochirí.

La gran rebelión tuvo, entonces, un carácter regional con una agenda que, sobre todo, se aplicaba al sur andino. Esta respondía a intereses y demandas de quienes eran parte del engranaje del circuito comercial de Cuzco a Potosí, ruta que, de esta manera, delimitó el radio de acción del movimiento tupacamarista, especialmente en la segunda fase. Fue, sin duda, una insurrección más bien insular que general, circunscrita al Bajo y el Alto Perú; al expandirse, no alcanzó a estremecer al norte del Virreinato -que mantuvo básicamente una posición expectante-, aunque en la documentación colonial se le denomine "sublevación general". Es preciso puntualizar que esta pasividad de parte de la región norte no se debió a que las noticias no llegaran (Thomson, 2016, p. 109), ${ }^{79}$ en la

78 AGI. Audiencia de Lima, leg. 663, citado en O'Phelan (2012b, p. 700)

79 El autor considera que el movimiento de Túpac Amaru no trascendió más allá de su región por falta de prensa escrita. Esta explicación no funciona en el caso del norte del virreinato peruano que, aunque estuvo enterado de los acontecimientos subversivos, no se plegó a la gran rebe- 
medida en que la gran rebelión se mantuvo en pie casi por un año. Probablemente el norte no consiguió identificarse ni con el programa ni con el manejo político del cacique de Tinta y sus seguidores. Por ello, no hizo suya esta rebelión.

Las juntas de gobierno surgieron a partir de 1809 en espacios tan equidistantes como La Paz y Quito, y en 1810 se instalaron juntas en Buenos Aires, Santiago, Bogotá y Caracas, de modo que cubrían un amplio espacio de la América española. Ello se debió a que el problema del vacío de poder dejado por Fernando VII y la inminente necesidad de hacer respetar los derechos otorgados a los españoles-americanos comprometieron a Hispanoamérica de forma general. Las juntas de gobierno fueron un fenómeno tan extendido como esperado. Esta característica produjo que se perciba la gran rebelión como un movimiento más circunscrito a un espacio concreto: el sur andino, sobre todo cuando se le compara con el despliegue de focos insurreccionales activos entre 1809-1814 a lo largo y ancho del territorio americano pero que, a pesar de la distancia, gracias al periodismo y el recurso de la correspondencia, ${ }^{80}$ dialogaron constantemente entre sí, y se mantuvieron informados de los acontecimientos. Los mecanismos empleados para la circulación de noticias en el temprano siglo XIX marcan también una clara diferencia entre las dos coyunturas: se debe tener en cuenta que Túpac Amaru recurrió fundamentalmente a decretos y manifiestos como material de apoyo, y al gremio de arrieros para que los circularan. En cambio, indudablemente, la difusión del periodismo en el que se respaldaron las juntas tuvo un mayor impacto, lo que ayudó a brindar soporte político e ideológico

lión.

80 Para el tema de la correspondencia, véase el reciente libro de Mónica Ricketts, Who Should Rule? Men of Arms, the Republic of Letters, and the Fall of the Spanish Empire (2017). Resulta de particular interés el Capítulo VI, "Abascal and the Problem of Letters in Peru, 1806-1816". 
a sus gobiernos. Además, quedó claro que el periodismo era un recurso vital en la construcción de la opinión pública.

En este sentido, es importante destacar que el fenómeno del americanismo ya aparece, de forma incipiente, en la temprana independencia y, precisamente, en la composición de las juntas. Limeños y arequipeños integraron la Junta Tuitiva de La Paz, así como clérigos nacidos en Piura y en Lima fueron voceros de la segunda junta de gobierno quiteńa, presidida por el obispo José Cuero y Caicedo, quien en 1815 falleció en Lima (Klaiber, 2013, p. 83). Un bonarense como Castelli fue invocado en los movimientos de Tacna y Huánuco. El clérigo tucumano Ildefonso Muñecas participó de las juntas de La Paz y del Cuzco. Igualmente, los dos abogados considerados los autores intelectuales de la junta de "los marqueses" de 1809 en Quito no eran quiteños (Torre Reyes, 1990, p. 220): Juan de Dios Morales era nacido en Antioquía, Nueva Granada, y Manuel Rodríguez de Quiroga era natural de Chuquisaca, en el Alto Perú. Todos eran criollos y mestizos, o-como ahora se les denominaba- españoles-americanos, y tenían un objetivo común: buscar primero las autonomías regionales, pero como un paso previo a obtener la independencia de España.

Cabe destacar que, en el contexto de las juntas de gobierno, apareció un sector que no tuvo la misma presencia ni influencia durante la gran rebelión. Mientras Túpac Amaru se apoyó básicamente en sus escribanos para la redacción de los documentos requeridos durante la insurrección, las juntas dispusieron de la presencia de abogados, que dieron el respaldo necesario a la elaboración de leyes y constituciones. La figuración y compromiso de los abogados -considerados la "inteligencia" de las juntas- no pasaron inadvertidos a las autoridades peninsulares, quienes los persiguieron e, incluso, ejecutaron para evitar su influencia política, al verlos como un inminente peligro. Según indica Víctor Uribe, la consigna 
entre los realistas era “¡dar muerte a los abogados!” (Uribe, 1995).

En este contexto, por primera vez se convocó a elecciones y se envió a la península a los representantes de los diferentes virreinatos y capitanías generales que tuvieron voz y voto, pero en un porcentaje menor a los diputados de España, lo cual cuestiona el principio de la igualdad de derechos (Chust, 2007, p. 33). En Cádiz, confluyeron delegados peruanos, chilenos, neogranadinos, venezolanos, mexicanos, cubanos -quienes, ante todo, eran americanos-; estos tuvieron la oportunidad de dialogar entre sí y dar las pautas para, luego, redactar la Constitución Liberal de 1812, que fue para España y América. Darles un espacio a los americanos en las Cortes fue la estrategia utilizada para intentar retrasar el proceso de independencia, ya en marcha. Como señalaba Abascal, la pérdida de América se podía retardar, pero era inevitable; lo que había que hacer era evitar "el contagio de la insurrección" (Abascal, 1944, p. 148).

También queda claro que tres fuerzas políticas emergieron en el período de las juntas de gobierno y se hicieron más sólidas en la segunda fase de la independencia: la de los proyectos continentales de San Martín y Bolívar, que se catapultaron en la temprana república. Estas fueron el Ejército, la Iglesia y el Poder Judicial, representado por los abogados. Emergieron en la temprana independencia, se consolidaron en su fase tardía y siguieron vigentes durante el resto del siglo XIX.

\section{Reflexiones finales. El Trienio Liberal}

Sin embargo, en 1820, durante el Trienio Liberal, cuando se trató de aplicar una política de elecciones con el fin de contar con una representación americana, como había ocurrido entre 1811 y 1814 , ya los avances de la independencia habían cambiado las reglas de juego y era difícil dar marcha atrás. En 
esta ocasión, la disposición para enviar diputados a las Cortes fue menos entusiasta y más crítica, y se opuso cierta resistencia. El tiempo no había pasado en vano y, en seis ańos, la maduración política de los americanos había sido notable. El Trienio Liberal (1820-1823) se encargó de tomar el pulso a las modificaciones experimentadas.

Para 1820, las Provincias Unidas del Río de la Plata y Chile ya habían logrado consolidar su independencia; Bolívar había triunfado en Boyacá y, de esta manera, perfilaba su proyecto de la Gran Colombia. Al año siguiente, San Martín declaró desde Lima la independencia del Perú y, en 1821, México, a partir del Plan de Iguala, se convirtió también en libre e independiente. Los dos virreinatos más antiguos de América se apartaban, así, de la monarquía española. Prácticamente toda Hispanoamérica estaba convulsionada y apuntaba hacia la ruptura con Espańa. En definitiva, no se trataba de la coyuntura de 1808 con el rey cautivo; ahora los liberales habían apartado al monarca del poder, debido a su conservadurismo intransigente o su "absolutismo consagrado", lo que demostraba que Fernando VII había dejado de ser El Deseado.

Si bien el Trienio Liberal creó expectativas tanto en San Martín como en Bolívar - por la presunción de que los liberales espańoles podrían ser más proclives a entender y ratificar la independencia de América-, ambos se equivocaron rotundamente. La España liberal no estaba dispuesta a perder sus colonias, donde había cimentado sus intereses económicos y comerciales por siglos, los cuales pretendía defender y no abandonar. San Martín y Bolívar sí acertaron en asumir que, con los disturbios provocados en España y con las confrontaciones permanentes entre liberales y conservadores, la metrópoli no estaría en condiciones de remitir refuerzos militares a América, donde un ejército realista cada vez más desgastado tenía que enfrentar a los patriotas, mejor organizados y equipados gracias a los años de experiencia en la lucha armada; 
además, muchos habían sido entrenados en las filas realistas. España estaba, entonces, combatiendo en desventaja: por el sur, enfrentaba al ejército libertador y, por el norte, al grancolombiano. El primero venía victorioso de la batalla de Maipú, en Chile; el segundo, de la batalla de Boyacá, la entrada a Colombia. Ambos habían posado sus ojos en la liberación del Perú que, a su entender, sellaría la independencia de América del Sur.

En términos de la composición social y el liderazgo de la guerra, también había habido alteraciones importantes. Mientras en la gran rebelión los caciques jugaron un papel relevante con Túpac Amaru a la cabeza, el cacique Pumacahua tuvo un papel menos protagónico en la junta cuzqueña de 1814 y, aparentemente, no contó con capacidad de convocatoria entre otros caciques para que lo secundaran. Para el momento del Trienio Liberal -cuando llegó San Martín al Perú-, el único cacique que tuvo una actuación bélica a favor de los patriotas fue Ignacio Quispe Ninavilca, de Huarochirí, quien participó como jefe de guerrillas: definitivamente, el liderazgo de los caciques pasaba por una nueva faceta. Las guerrillas y montoneras, en las que participaron los sectores populares, establecieron un nuevo estilo de confrontación armada consistente en ataques sorpresivos, y con el encargo de resguardar Lima y de bloquear el avance de las fuerzas realistas.

Además, con el Trienio Liberal, se puso nuevamente en vigencia la Constitución gaditana de 1812, que propugnaba 62 la abolición del tributo indígena y de los señoríos. Es decir, cuando San Martín decretó la abolición del tributo en 1821, simplemente ratificó una medida que ya se había puesto en vigor con la reintroducción de la Constitución Liberal en 1820. De igual manera, cuando Bolívar promulgó la abolición de los cacicazgos en 1825, siguió la política trazada por la Constitución gaditana activada en el Trienio Liberal, la cual erradicaba los señoríos y, en ese sentido, no hay que 
olvidar que los caciques eran señores naturales. Así, ambas medidas -la abolición de los tributos y la de los señoríos- se remontaban a 1812 y las Cortes de Cádiz: no eran una innovación. Esto evidencia la empatía de San Martín y Bolívar con algunas de las medidas liberales.

Un grupo social que mostró visibilidad en la segunda fase de la independencia fue el conformado por los esclavos y las castas de color, quienes habían tenido un perfil bajo durante la gran rebelión y las juntas de gobierno. Tempranamente, tanto San Martín como Bolívar descubrieron que podían ser importantes aliados si los integraban a los ejércitos patriotas a cambio de ofrecerles la libertad, por la que tendrían que luchar entre cinco y seis años. Aparecen, entonces, los regimientos de libertos, por los cuales tanto San Martín como Guillermo Miller sentían respeto y gratitud. En el contexto del Trienio Liberal, la decisión de las castas de color de unirse a las fuerzas patriotas tendrá una mayor trascendencia, ya que mientras la Constitución Liberal de 1812, reintroducida en 1820, negó la abolición de la esclavitud y el derecho a la ciudadanía de la población afrodescendiente, tanto San Martín como Bolívar le ofreció la libertad si luchaba por la independencia.

El clero que había redactado pronunciamientos en la gran rebelión y tomado las armas durante las juntas de gobierno, en el contexto del protectorado recurrió sustancialmente al púlpito para alentar a los feligreses o bien a favor de los patriotas o bien en apoyo de los realistas. Fue un clero dividido, pues, muchos de ellos - de la alta y baja jerarquía eclesiástica $y$, sobre todo, peninsulares de origen- optaron por salir del Perú luego de firmada la Declaración de la Independencia en 1821. Tal fue el caso del arzobispo de Lima, el andaluz Bartolomé María de las Heras, quien, por diferencias irreconciliables con San Martín y su ministro Bernardo Monteagudo, tomó la decisión de regresar a la península utilizando la ruta 
de Río de Janeiro, desde donde hizo declaraciones demoledoras contra el protectorado. Fueron sobre todo miembros del bajo clero los que optaron por permanecer en el Perú. Sin embargo, en esta etapa final de la independencia, los eclesiásticos ya no tuvieron necesidad de involucrarse en los enfrentamientos bélicos; la represión que recayó sobre ellos en la coyuntura de las juntas de gobierno por haberse propasado en sus funciones probablemente les sirvió de lección. Además, para el período del Trienio Liberal, el ejército patriota ya estaba bastante mejor constituido, con los refuerzos llegados, primero, desde Chile y, luego, de la Gran Colombia.

Un hecho que no deja de sorprender es que, hasta antes de perderse el Perú, el virrey José de La Serna, desde el Cuzco, continuó reclamando con insistencia que se le remitieran barcos, hombres y armas, que nunca arribaron. Por otro lado, en 1822, los peninsulares emigrados del virreinato peruano y refugiados en Río de Janeiro aún guardaban la esperanza de que llegaran los ansiados refuerzos para poder "reconquistar" el Perú y recuperar sus puestos y propiedades. No estaban dispuestos a aceptar que el proceso de independencia ya era irreversible.

No está demás destacar las diferencias entre las estrategias militares y las visiones políticas de los dos últimos virreyes del Perú. Joaquín de la Pezuela abogaba por no entregar Lima, porque, de hacerlo, se perdería el Perú, mientras que para La Serna la resistencia había que llevarla a cabo al interior del Virreinato. Probablemente, en ese sentido, La Serna tuvo razón, ya que trasladó el epicentro del Virreinato al Cuzco y, desde ahí, pudo gobernar tres años más, aunque ello significara tener un Perú dividido.

En este sentido, mientras la gran rebelión contra el mal gobierno se concentró en el sur andino, durante la etapa final de la independencia, ese mismo espacio albergó al último 
virrey y fue desde el Cuzco que se orquestó la guerra contra la causa patriota. Lima demostró, entonces, que no era el Perú, como lo había pensado Pezuela. Los armisticios que acordaron tanto Pezuela como La Serna con San Martín dividieron al Perú: el norte sirvió de base al ejército libertador y el sur, para recibir al virrey y acantonar a las fuerzas realistas. Solo con la llegada de Sucre y Bolívar, en 1823, se quebró esta división imaginada al darse las últimas batallas de Junín y Ayacucho precisamente en el territorio sobre el que gobernaba La Serna. En 1824, el Perú, aparentemente, estaba en condiciones de revertir esta fractura regional luego de incorporar el territorio del surandino, anteriormente en manos realistas; sin embargo, esta fisura estructural entre regiones, que ya se avistaba durante la gran rebelión y las juntas de gobierno, seguiría marcando, hasta bien entrada la república, la falta de diálogo y compenetración entre el norte y el sur del Perú.

Recibido: 25 de agosto de 2020

Aprobado: 15 de noviembre de 2020

\section{Archivos y fuentes primarias}

Archivo General de Indias, Sevilla (AGI)

Audiencia de Charcas, leg. 319.

Audiencia de Lima, leg. 663.

Audiencia de Lima, leg. 665.

Audiencia de Lima, leg. 1039.

Audiencia de Lima, leg. 1052.

Audiencia del Cuzco, leg. 32.

Audiencia del Cuzco, leg. 33.

Museo Británico, Londres (MBL)

Egerton 1218. 
Additional (ms.) 17, 587.

Archivo Regional del Cuzco (ARC)

Real Audiencia. Causas Ordinarias, leg. 2.

Real Audiencia. Causas Ordinarias, leg. 10.

Colección Documental de la Independencia del Perú (CDIP), Lima, tomo III, vol. 2, 1971; vol. 7, 1973; vol. 8, 1974.

\section{Bibliografía citada}

Abascal y Sousa, J. F. de.

(1944) Memoria de Gobierno. 2 volúmenes. Introducción de Vicente Rodríguez Casado. Escuela de Estudios Hispanoamericanos.

Angles Vargas, V.

(1975) El cacique Tambohuacso: historia de un proyectado levantamiento contra la dominación española. Industria Gráfica.

Anna, T.

(1986) España y la independencia de América. Fondo de Cultura Económica.

Arnade, C.

The Emergence of the Republic of Bolivia. University of Florida Press.

66

Arce Aguirre, R.

(1979)

Participación popular en la independencia boliviana. Editorial Don Bosco.

Berquist, E. S.

(2014) The Bishop's Utopia. Envisioning Improvement in Colonial Peru. University of Pennsylvania Press. 
Bonilla, H. y Spalding, K.

(1981) "La independencia del Perú: las palabras y los hechos". En H. Bonilla et ál., La independencia del Perú. Instituto de Estudios Peruanos.

Brading, D. (1994)

Church and State in Bourbon Mexico. The Diocese of Michoacán, 1749-1810. Cambridge University Press.

Burkholder, $\mathrm{M}$.

(1972) "From Creole to Peninsular: the Transformation of the Audiencia de Lima”. Hispanic American Historical Review, 52 (3), 395-415.

Bushnell, D.

"The independence of Spanish South America". En L. Bethell (Ed.), The Independence of Latin America (pp. 99-156). Cambridge University Press.

Busto Duthurburu, J. A. del.

(1981) José Gabriel antes de su rebelión. Fondo Editorial de la Pontificia Universidad Católica del Perú.

Cahill, D.

(2011) "New Viceroyalty, New Nation, New Empire: A Transnational Imaginary for Peruvian Independence". Hispanic American Historical Review, 91 (2), 203-235.

Cahill, D.

(2003)

"Primus interpares. La búsqueda del marquesado de Oropesa camino a la gran rebelión (1741-1780)". Revista Andina, (37), 9-52.

Cahill, D.

(2002) From Rebellion to Independence in the Andes: Soundings from Southern Peru, 1756-1830. Aksont Academic Publishers. 
Cahill, D.

(1990) "Taxonomy of a Colonial Riot: The Arequipa Disturbances of 1780". En J. Fisher et al. (Eds.), Reform and insurrecction in bourbon New Granada and Peru (pp. 255-291). Lousiana State University Press.

Cahill, D.

(1984)

"Curas and Social Conflict in the Doctrinas of Cuzco, 1780-1814”. Journal of Latin American Studies, $16(2), 241-276$.

Callaham, W.

(1989) Iglesia, poder ysociedad en España, 1750-1874. Editorial Nerea.

Castro, I. de.

Relación del Cuzco. Prólogo de Carlos Daniel Valcárcel. Universidad Nacional Mayor de San Marcos.

Céspedes del Castillo, G.

(1947) Lima y Buenos Aires, repercusiones económicas y politicas de la creación del virreinato del Plata. Escuela de Estudios Hispanoamericanos.

Chassin, J. (2006)

"El rol de los alcaldes de indios en las insurrecciones andinas (Perú a inicios del siglo XIX)". Boletín del Instituto Francés de Estudios Andinos, 37 (1), $227-$ 242.

68 Chust, $M$.

(2007) “Un bienio trascendental: 1808-1810”. En M. Chust (Coord.), 1808. La eclosión juntera en el mundo hispano (pp. 11-50). Fondo de Cultura Económica y El Colegio de México.

Chust, M.

(1999) La cuestión nacional americana en las Cortes de Cádiz. Fundación Instituto Historia Social e Instituto de 
Investigaciones Históricas de la Universidad Nacional Autónoma de México.

Cortés Peña, A. L.

(1989) La política religiosa de Carlos III. Servicio de Publicaciones de la Universidad de Granada.

Delemeau, J.

(2002) El miedo en Occidente. Siglos XIV-XVIII. Una ciudad sitiada. Taurus Pensamiento y Santillana Ediciones.

Díaz Rementería, C.

(1974) "El delito de lesa majestad humana en los indios. Un estudio basado en la sublevación de Túpac Amaru (1780-1781)". Anuario de Estudios Americanos. (31), 229-242.

Durand Flórez, L.

(1985) Criollos en conflicto. Cuzco después de Túpac Amaru. Multiservice Ltda.

Eguiguren, L. A.

(1914) La Revolución de 1814. Oficina Tipográfica de La Opinión Nacional.

Fisher, J.

"Royalism, Regionalism and Rebellion on Colonial Peru, 1808-1815”. Hispanic American Historical Review, 59 (2), 232-257.

Fisher, J.

(1976) "La rebelión de Túpac Amaru y el programa imperial de Carlos III". En A. Flores Galindo (Ed.), Túpac Amaru II. Antología (pp. 107-128). Retablo de Papel Ediciones.

Fisher, J.

(1970) Government and Society in Colonial Peru. The Intendant System, 1784-1814. The Anthole Press. 
Fisher, L. E.

(1966) The Last Inca Revolt, 1780-1783. University of Oklahoma Press.

Flores Galindo, A.

(1987) Buscando un inca: identidades y utopia en los Andes. Instituto de Apoyo Agrario.

Fontana, J.

La crisis del Antiguo Régimen, 1808-1833. Editorial Crítica.

Fradera, J.

Gobernar colonias. Ediciones Península.

Galdós, G.

La rebelión de los pasquines. Editorial Universitaria.

Ganster, P.

(1986)

"Churchmen". En L. Schell y S. Midgen (Eds.), Cities and Society in Colonial Latin America (pp. 137164). University of New Mexico Press.

Garrett, D. (2005)

Shadows of Empire. The Indian Nobility of Cuzco, 1750-1825. Cambridge University Press.

Garzón, E.

“1780: clero, elite local y rebelión.” En C. Walker (Comp.), Entre la retórica y la insurgencia: las ideas y los movimientos sociales en los Andes, siglo XVIII (pp. 245-272). Centro de Estudios Regionales Andinos Bartolomé de las Casas.

Glave, L. M. (2001)

"Antecedentes y naturaleza de la Revolución del Cuzco de 1814 y el primer proceso electoral". En S. O'Phelan Godoy (Ed.), La independencia del Perú. De los Borbones a Bolivar (pp. 77-98). Instituto Riva 
Agüero de la Pontificia Universidad Católica del Perú.

Goldman, N. (Ed.)

(2008) Lenguaje y revolución. Conceptos politicos clave en el Rio de la Plata, 1780-1850. Prometeo Libros.

Guerra, F.-X.

(1995) "Lógicas y ritmos de las revoluciones hispanoamericanas". En F.-X. Guerra (Coord.). Las revoluciones hispanoamericanas: independencias americanas y liberalismo español (pp. 13-46). Editorial Complutense S.A.

Guerra, F.-X.

Modernidad e independencias. Ensayos sobre las revoluciones hispanoamericanas. Editorial Mapfre.

Guimerá, A.

El reformismo borbónico. Alianza Editorial.

Hamnett, B.

"El virrey Abascal y sus cinco homólogos novohispanos, 1806-1816: un estudio comparativo". En S. O’Phelan Godoy y G: Lomné (Eds.), Abascal y la contraindependencia de América del Sur (pp. 19-52). Fondo Editorial de la Pontificia Universidad Católica del Perú e Instituto Francés de Estudios Andinos.

Hünefeldt, C.

"Los indios y la Constitución de 1812". Allpanchis Phuturinqa, (11-12), 33-57.

Iberico, R. (2016)

"Discursos políticos y religiosos durante la rebelión del Cuzco de 1814”. En S. O'Phelan Godoy (Ed.). 1814: La Junta de Gobierno del Cuzco y el sur andino (pp. 267288). Fondo Editorial de la Pontificia Universidad Ca- 
tólica del Perú, Instituto Francés de Estudios Andinos y Fundación Bustamante de la Fuente.

Izquierdo, J., López, J., Pablo Gafas, J. de, Mulas, J. de las, y Méndez R.

"La reforma de regulares durante el reinado de Carlos III. Una valoración a través del ejemplo madrileño”. En Equipo Madrid de Estudios Históricos, Carlos III, Madrid y la Ilustración (pp. 189-222). Siglo XXI de España Editores, S. A.

Kaperer, J.-N.

Rumores. El medio de difusión más antiguo del mundo. Editorial Plaza \& Janés.

Klaiber, J.

$$
\begin{aligned}
& \text { "El clero ilustrado en tiempo de Abascal". En S. } \\
& \text { O’Phelan Godoy y G. Lomné (Eds.), Abascal y la } \\
& \text { contraindependencia de América del Sur (pp. 75-88). } \\
& \text { Fondo Editorial de la Pontificia Universidad Católi- } \\
& \text { ca del Perú e Instituto Francés de Estudios Andinos. }
\end{aligned}
$$

Klaiber, J. (2001)

"El clero y la independencia del Perú". En S. O'Phelan Godoy (Ed.), La independencia del Perú. De los Borbones a Bolivar (pp. 119-136). Instituto Riva Agüero.

Larrea, C. M.

El barón de Carondelet. XXIX Presidente de la Real Audiencia de Quito. Corporación de Estudios y Publicaciones.

Lavallé, B.

Las promesas ambiguas. Criollismo colonial en los Andes. Instituto Riva Agüero. 
Lewin, B.

(1967) La rebelión de Túpac Amaru y los orígenes de la independencia de Hispanoamérica. Sociedad Editorial Latino Americana.

Lorandi, A. M. y Bunster, V.

(2013) La pedagogía del miedo. Los Borbones y el criollismo en el Cuzco, 1780-1790. Centro de Estudios Regionales Andinos Bartolomé de las Casas e Instituto Francés de Estudios Andinos.

Lynch, J.

(1996) "El reformismo borbónico en Hispanoamérica". En A. Guimerá (Ed.), El reformismo borbónico (pp. 3760). Alianza Editorial.

Lynch, J.

(1986) The Spanish Revolutions, 1808-1826. W. W. Norton \& Company.

Lynch, J.

(1958) Spanish Colonial Administration, 1782-1810. The Intendant System in the Viceroyalty of the Rio de la Plata. University of London, Anthlone Press.

Madrazo, G.

(2001) “Túpac Amaru, la rebelión, dios y el rey”. Andes (12), $1-40$.

Marks, P.

(2007) Deconstructing Legitimacy. Viceroys, Merchants and the Military in Late Colonial Peru. The Pennsylvania State University Press.

Martínez Riaza, A.

(1985) La prensa doctrinal en la Independencia del Perú, 18111824. Instituto de Cooperación Iberoamericana. 
Molina Martínez, M.

(2010) "Presencia del clero en la revolución cuzqueña de 1814: ideas y actitudes de Francisco Carrascón". Revista Complutense de Historia de América, 36, 209-231.

Najarro, $M$.

(2016)

"Constitucionalismo y revolución: Cuzco 18121814”. En S. O’Phelan Godoy (Ed.), 1814: La Junta de Gobierno del Cuzco y el sur andino (pp. 129-160). Fondo Editorial de la Pontificia Universidad Católica del Perú, Instituto Francés de Estudios Andinos y Fundación Bustamante de la Fuente.

Navarro García, L.

(2000) "Fluctuaciones de la política colonial española de Carlos III a Isabel II". En Centro de Investigaciones de América Latina (Coord.), De súbditos del rey a ciudadanos de la nación (pp. 75-92). Publicacions de la Universitat Jaume I.

Navarro, J. G.

(1962) La revolución de Quito del 10 de agosto de 1809. Editorial Fray Jodoco Ricke.

O'Phelan Godoy, S.

(2019) "El norte patriota y el sur realista. La división territorial del Perú en el contexto de la independencia (1820-1824)". En S. O’Phelan Godoy y A. C. Ibarra (Eds.), Territorialidad y poder regional de las intendencias en las independencias de México y Perú (pp. 389-438). Fondo Editorial del Congreso del Perú.

O'Phelan Godoy, S.

(2016a) Siete ensayos sobre la gran rebelión. De Túpac Amaru a Túpac Catari. Dirección Desconcentrada de Cultura de Cuzco-Ministerio de Cultura. 
O'Phelan Godoy, S.

(2016b) "Huánuco (1812) y el Cuzco (1814): entre la promulgación y la derogación de la Constitución de Cádiz". En S. O'Phelan Godoy (Ed.), 1814: La Junta de Gobierno del Cuzco y el sur andino (pp. 291-314). Fondo Editorial de la Pontificia Universidad Católica del Perú, Instituto Francés de Estudios Andinos y Fundación Bustamante de la Fuente.

O'Phelan Godoy, S.

(2014) La independencia en los Andes. Una historia conectada. Fondo Editorial del Congreso del Perú.

O'Phelan Godoy, S.

(2013) Mestizos reales en el virreinato del Perú. Indios nobles, caciques y capitanes de mita. Fondo Editorial del Congreso del Perú.

O'Phelan Godoy, S.

(2012a) Un siglo de rebeliones anticoloniales. Perú y Bolivia, 1700-1783. Instituto Francés de Estudios Andinos, Instituto de Estudios Peruanos.

O'Phelan Godoy, S.

(2012b) "Huarochirí en el siglo XVIII. Una provincia entre dos rebeliones". En M. Guerra Martinière y R. Sánchez-Concha (Eds.), Homenaje a José Antonio del Busto Duthurburu (pp. 687-706). Fondo Editorial de la Pontificia Universidad Católica del Perú.

O'Phelan Godoy, S.

(2012c) "El Perú de Abascal: entre la Constitución de Cádiz, la Lima fidelista y la reformulación del espacio virreinal”. En M. Chust e I. Frasquet (Eds.), La patria no se hizo sola. Las revoluciones de independencias iberoamericanas (pp. 195-228). Silex Ediciones. 
O'Phelan Godoy, S.

(2007) "Ciudadanía y etnicidad en la Cortes de Cádiz". En C. Aljovín y N. Jacobsen (Ed.), Cultura politica en los Andes (pp. 267-290). Universidad Nacional Mayor de San Marcos e Instituto Francés de Estudios Andinos.

O’Phelan Godoy, S.

(2005a) "Orden y control en el siglo XVIII. La política borbónica frente a la corrupción fiscal, comercial y administrativa”. En F. Portocarrero (Ed.), El pacto infame. Estudios sobre la corrupción en el Perú (pp. 1334). Red para el Desarrollo de las Ciencias Sociales.

O'Phelan Godoy, S.

(2005b) "Entre Gálvez y Areche: el factor acumulativo de presión fiscal y la gran rebelión de 1780". M. Guerra y D. Rouillon (Eds.), Historias paralelas. Actas del Primer Encuentro de Historia Perú-México (pp. 213236). Fondo Editorial de la Pontificia Universidad Católica del Perú y El Colegio de Michoacán.

O'Phelan Godoy, S.

(1997) Kurakas sin sucesiones. Del cacique al alcalde de indios. Perú y Bolivia, 1750-1835. Centro de Estudios Regionales Andinos Bartolomé de las Casas.

O'Phelan Godoy, S.

(1995) Lagran rebelión en los Andes: de Túpac Amaru a Túpac Catari. Centro de Estudios Regionales Andinos Bartolomé de las Casas y PetroPerú.

O'Phelan Godoy, S.

(1988) "Por el rey, religión y la patria. Las juntas de gobierno de 1809 en La Paz y Quito". Boletín del Instituto Francés de Estudios Andinos, 17 (2), 61-80. 
O'Phelan Godoy, S.

(1984) "El mito de la independencia concedida. Los programas políticos del siglo XVIII y del temprano XIX en el Perú y el Alto Perú (1730-1814)". En I. Buisson (Ed.), Problemas de la formación del Estado y de la nación en Hispanoamérica (pp. 55-92). Intenationes.

O'Phelan Godoy, S.

(1978) "El sur andino a fines del siglo XVIII: cacique o corregidor". Allpanchis Phuturinqa, (11-12), 17-32.

Peralta Ruíz, V.

(2015) "Un lenguaje político para reformar. La recepción del liberalismo hispánico en Perú entre las Cortes de Cádiz y el Trienio Liberal”. En P. González Bernaldo de Quirós (Ed.), Independencias iberoamericanas. Nuevos problemas y aproximaciones (pp. 177-195). Fondo de Cultura Económica.

Peralta Ruíz, V.

(2012) "La participación popular en las juntas de gobierno peruanas de Huánuco (1812) y Cuzco (1814)”. En M. Cagiao Vila y J. Portillo Valdés (Coords.), Entre imperio y naciones. Iberoamérica y el Caribe en torno a 1810. Cátedra Juana de Vega y Universidad de Santiago de la Compostela.

Puente Candamo, J. A. de la.

(1992) La independencia del Perú. Editorial Mapfre.

Ricketts, M.

(2017)

Who Should Rule? Men of Arms, the Republic of Lettes, and the Fall of the Spanish Empire. Oxford University Press.

Rieu-Millan, M. L.

(1999) Los diputados en las Cortes de Cádiz. CSIC. 
Roca, J. L.

(2007) Ni con Lima ni con Buenos Aires. La formación de un Estado nacional en Charcas. Plural Editores e Instituto Francés de Estudios Andinos.

Roedl, B.

(2002)

"Causa Tupa Amaro. El proceso a los tupamaros en Cuzco, abril-julio de 1781”. Revista Andina (34), 99-121.

Sala I Vila, N.

(1995) "La rebelión de Huarochirí de 1783". En C. Walker (Comp.). Entre la retórica y la insurgencia: las ideas y los movimientos sociales en los Andes, siglo XVIII (pp. 273-308). Centro de Estudios Regionales Andinos Bartolomé de las Casas.

Sala I Vila, N.

"La participación indígena en la rebelión de Angulo y Pumacahua, 1814-1816”. P. García Jordán (Coord.), Conquista y resistencia en la historia de América. $\mathrm{Pu}-$ blicacions de la Universitat de Barcelona.

Seiner, L.

(2013)

"Una rebelión a la deriva: fisuras y represión realista en Tacna, 1811”. En S. O’Phelan Godoy y G. Lomné (Eds.), Abascal y la contraindependencia de América del Sur (pp. 53-74). Fondo Editorial de la Pontificia Universidad Católica del Perú e Instituto Francés de Estudios Andinos.

Soux, M. L. (2016)

"La Paz en 1811 y 1814 en el contexto de una guerra continental”. En S. O'Phelan Godoy (Ed.), 1814: La Junta de Gobierno del Cuzco y el sur andino (pp. 459482). Fondo Editorial de la Pontificia Universidad Católica del Perú, Instituto Francés de Estudios Andinos y Fundación Bustamante de la Fuente. 
Sparks, M. C.

(1972) The Roles of the Clergy in the Struggle for Independence in Peru. Tesis para optar el título de doctora en Historia. University of Pittsburg. Pittsburg.

Thomson, S.

(2016) "Sovereignity Disavowed: the Tupac Amaru Revolution in the Atlantic World". Atlantic Studies, 3 (13), 107-129.

Tío Vallejo, G. y Gayol, V.

(2005) "Hacia el altar de la patria. Patriotismo y virtudes en la construcción de la conciencia militar entre las reformas borbónicas y la revolución de independencia”. En J. Ortiz (Coord.), Fuerzas militares en Iberoamérica. Siglos XVIII y XIX (pp. 111-137). El Colegio de México, El Colegio de Michoacán y Universidad Veracruzana.

Torero Gomero, C. F.

(1969-1971) "Establecimiento de la Audiencia del Cuzco". Boletín del Instituto Riva Agüero, (8), 374-522.

Torre Reyes, C. de la.

(1990) La revolución de Quito del 10 de agosto de 1809. Banco Central del Ecuador.

Troiullot, M. R.

Silencing the Past. Power and the Production of History. Beacon Press.

Uribe, $\mathrm{V}$.

(1995) "Kill All the Lawyers! Lawyers and the Independence Movement in New Granada, 1809-1820". The Americas, 52 (2), 175-210.

Vargas Ugarte, R.

(1958) Historia del Perú. Emancipación (1809-1825). Imprenta López. 
Walker, C.

(2014) The Tupac Amaru Rebellion. The Belknip Press of Harvard University Press.

Wasserman, F.

(2013) "Entre dos fuegos: la política de Castelli en el Alto Perú”. En S. O'Phelan Godoy y G. Lomné (Eds.), Abascal y la contraindependencia de América del Sur (pp. 271-302). Fondo Editorial de la Pontificia Universidad Católica del Perú e Instituto Francés de Estudios Andinos.

Wasserman, F.

(2011). Juan José Castelli. De súbdito de la Corona a líder revolucionario. Edhasa. 